\title{
Recruitment of Antarctic krill Euphausia superba in the South Georgia region: adult fecundity and the fate of larvae
}

\author{
G. A. Tarling ${ }^{1, *}$, J. Cuzin-Roudy ${ }^{2}$, S. E. Thorpe $^{1}$, R. S. Shreeve1 ${ }^{1}$, P. Ward ${ }^{1}$, E. J. Murphy ${ }^{1}$ \\ ${ }^{1}$ British Antarctic Survey, Natural Environment Research Council, High Cross, Madingley Road, Cambridge CB3 0ET, UK \\ ${ }^{2}$ Observatoire Océanologique, Université Pierre et Marie Curie (Paris 6), CNRS (UMR 7093), 06230 Villefranche-sur-mer, France
}

\begin{abstract}
The high concentration of adult Antarctic krill Euphausia superba Dana around South Georgia, Antarctica, is a product of immigration and not local recruitment. We investigated whether reproduction and early larval development are the cause of local recruitment failure. It was found that the majority of adult females were reproductively active in summer and that there was a comparatively high investment in the ovary, reaching up to $46 \%$ of the total wet weight of the krill. The corresponding egg batches were amongst the largest ever reported for E. superba. A semi-empirical model predicted that $11 \%$ of females completed just 1 spawning episode per year, $60 \%$ completed 2 ,

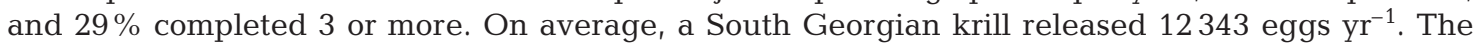
eggs were unable to complete the descent-ascent developmental cycle on-shelf because the bathymetry was too shallow but, off-shelf, they were predicted to sink to between 490 and $520 \mathrm{~m}$ and return to the surface either as a metanauplius or 1st calyptopis stage with plenty of energy reserves remaining. Feeding conditions were adequate for the development of later larval stages once these reserves were exhausted. Although net surveys found calyptopis and early stage furcilia in the vicinity of South Georgia, numbers were mostly lower than predicted. Overall, reproduction or early stage development are successful in this region, leaving predation on larvae and advective export during winter as the main potential causes of local recruitment failure.
\end{abstract}

KEY WORDS: Reproduction - Advection - Ocean circulation and climate advanced model - OCCAM · Ascent-descent cycle $\cdot$ Fecundity $\cdot$ Predation $\cdot$ Southern Ocean $\cdot$ Polar regions

Resale or republication not permitted without written consent of the publisher

\section{INTRODUCTION}

South Georgia is close to the northern distributional limit of Antarctic krill Euphausia superba Dana and supports some of the highest concentrations of this species in the Southern Ocean. Such a pattern is unusual because the increasing inability of individuals to perform essential functions commonly results in abundance decreasing towards distributional boundaries (Brinton 1962). The breakdown in function is particularly seen in the capacity of individuals to reproduce successfully, manifested as an inability to develop secondary sexual characteristics and attain sexual maturity (Dalpadado \& Skjoldal 1991), to produce viable offspring (de Visser 1986) or to recruit offspring into the adult population (Ward et al. 1990). The first 2 scenarios are likely to result from the physiological stress of experiencing conditions at the limits of their tolerable range (Peck et al. 2004). The third may occur for additional reasons, which for krill include an inability to oppose unfavourable currents (Murphy et al. 1998) or to endure increased levels of predation (Murphy \& Reid 2001).

It has long been posited that the adult krill population at South Georgia is a product of immigration from upstream regions such as the Antarctic Peninsula (Ruud 1932), and recent modelling work has supported this view (Murphy et al. 2004). Why local recruitment does not take place at South Georgia is less well understood; Ruud (1932), for instance, believed that the site 
was unsuitable for spawning, but this fact has never been fully established. Moreover, there has not been a detailed investigation of whether individuals can attain sexual maturity in this region or whether eggs and larvae develop successfully. Identification of the steps in the reproduction and developmental cycles which are the cause of recruitment failure is important for determining the response of the species to potential future changes in environmental conditions and harvesting practices in the region.

Antarctic krill reproductive development goes through a number of phases during an annual cycle (Ross \& Quetin 2000) that have been categorised for females into 10 sexual development stages (SDS 1 to 10) by Cuzin-Roudy \& Amsler (1991). Krill spend their first year as larvae and juveniles (SDS 1) and do not develop secondary sexual characters until the spring of their second year, at which point they have attained sexual maturity (SDS 2) and are mated. Ovarian development starts when the young oocytes that have remained dormant over the winter period enter previtellogenesis (SDS 3 and 4), and accumulate glycoproteic yolk (Cuzin-Roudy 1993). Periodically, a batch of these oocytes attains a certain size and enters a cycle of lipid yolk accumulation, or vitellogenesis (SDS 5 and $6)$. The fully grown oocytes become mature ( $S D S 7$ ), after which the egg-batch is released in 1 to 3 spawns over several days (Cuzin-Roudy 1987). The postspawn ovary ( $S D S$ 8) may still contain a stock of previtellogenic oocytes and repeat cycles of vitellogenesis until the stock is exhausted. At the end of the season, residual oocytes left over from the previous spawning event undergo oosorption ( $S D S$ 9). At the same time, a new stock of young oocytes is formed and the ovary becomes regressed and reorganised (SDS 10) ready for the over-wintering period (Cuzin-Roudy 2000). The thelycum may also be regressed at this time (Denys \& McWhinnie 1982). If it survives the winter, the krill reenters previtellogenesis the following year at the onset of favourable conditions.

The fecundity of a population can be estimated by determining (1) the proportion of the population that is reproductively active, (2) the number of eggs released per spawning episode, (3) the frequency of spawning episodes and (4) the length of the reproductive season. Parameter 1 can be determined by examining ovaries in late-season samples; individuals that have been reproductively active will contain residual mature oocytes (SDS 9 and 10), whereas individuals that have remained immature will possess small, undeveloped oocytes ( $S D S$ 1) only. For Parameter 2, egg batch size is strongly correlated with body size (Cuzin-Roudy 2000) although this relationship appears to vary between regions (Jadzewksi et al. 1978, Ross \& Quetin 1983). Spawning-episode frequency and the length of the reproductive season (Parameters 3 and 4 ) are known to be variable between years and regions (Ross \& Quetin 2000). However, certain patterns that have been identified in krill allow us to make some inferences with regard to rates and timings. Cuzin-Roudy \& Buchholz (1999) found that the northern krill species Meganyctiphanes norvegica spawned in every other moult cycle during early premoult phase, and Euphausia superba appears to show a similar pattern (CuzinRoudy 1987, 2000). This enables the maximum frequency of spawning to be determined once the intermoult period (IMP) is known. The relationship between the first phytoplankton blooms of the season and the onset of previtellogenesis (Cuzin-Roudy \& Labat 1992) allow us some means of determining when reproductive activity probably started in any particular year. Ovarian examination of late season samples is a means of determining when reproductive activity ends.

Once spawned, offspring go through an ontogenetic migration, whereby they initially sink as embryos and then re-ascend as swimming larvae (Fraser 1936). It is known that the rates of sinking and re-ascent are intimately dependent on environmental factors such as specific density (Marschall 1983) and temperature (Ross et al. 1988). Hofmann et al. (1992) used such parameterisations to predict the depth-time trajectory of the early developmental stages in the Bransfield Strait-South Shetland Islands. They found that the presence of the relatively warm Circumpolar Deep Water was instrumental in accelerating development, allowing larvae to re-enter the food-rich surface waters long before energy reserves ran out. At the scale of the Southern Ocean, Hofmann \& Hüsrevolğlu (2003) showed that regional variations in bathymetry and the prevalent water masses resulted in different levels of success in the early developmental stages. This was believed to be influential in determining the circumpolar distribution of krill.

The principal aim of this study was to determine whether female reproductive activity or the development of early stages are the main causes of recruitment failure in the South Georgia region. Herein we develop models to predict patterns of reproduction and developmental success. These are parameterised with field data obtained over several years. Observations of larval distributions made during these and other campaigns are compared to our predictions.

\section{MATERIALS AND METHODS}

Post-larval population structure. Samples were taken from a survey carried out in 2003 by RRS 'James Clark Ross', which covered much of the Scotia Sea region. We focus on only the part of the survey that 


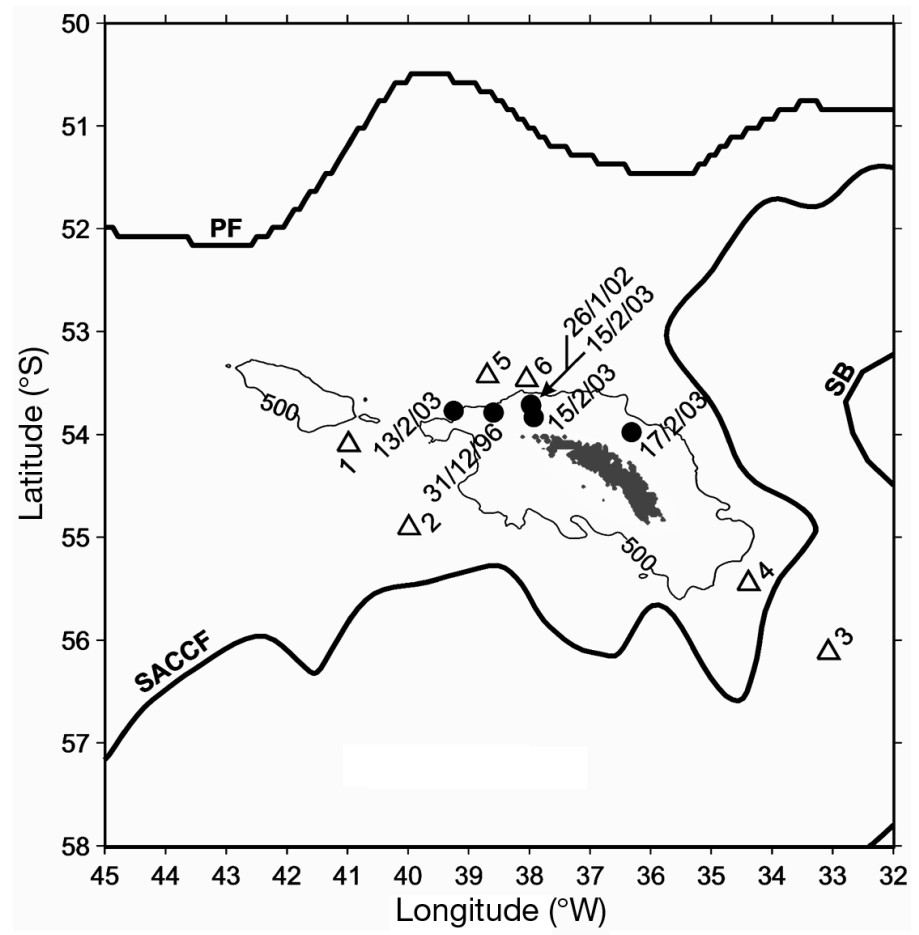

Fig. 1. Euphausia superba. Locations and dates $(\mathrm{d} / \mathrm{mo} / \mathrm{yr})$ of samples taken for ovarian examination $(\bullet)$ and of samples in which females with fully developed ovary were observed and advective fate of their larvae predicted $(\Delta)$. Exact locations and dates of latter stations are given in Table 6. PF: Polar Front (Moore et al. 1999); SACCF: Southern Antarctic Circumpolar Current Front (Thorpe et al. 2002); SB: Southern Boundary (Orsi et al. 1995)

was carried out in the South Georgia region during mid-February (Fig. 1). Krill sampling along the survey track was carried out opportunistically with an RMT8 net whenever krill swarms were located by the ship's echosounder (Simrard EK60). Around 20 separate catches of krill were taken in the South Georgia region.

A separate set of net hauls was carried out in a random fashion within a predefined region to the northwest of South Georgia in February 2003 to determine mean concentration. An RMT8 net was deployed in a double-oblique fashion such that Net 1 was open from the surface to the maximum depth and Net 2 open on the return to the surface. Deployments were made at 4 locations (co-ordinates in Table 1). The maximum sampling depth was $250 \mathrm{~m}$ in offshore locations and $10 \mathrm{~m}$ above sea-bottom on-shelf. Total net-catch abundances and flow meter records were taken to determine depth-integrated concentration (ind. $\mathrm{m}^{-2}$ ).

We investigated length-frequency data to confirm that the summer population lacked $\sim 12$ to 14 mo old individuals. Four samples from the February 2003 survey were combined and modes identified through segregating overlapping distributions with component fitting software (MIX 3.1; MacDonald \& Green 1988).
Table 1. Euphausia superba. Concentrations of adults captured by an RMT8 net deployed in a double-oblique fashion at 4 random locations within a predefined region northwest of South Georgia. Lat.: Latitude; Long.: Longitude

\begin{tabular}{|c|c|c|c|c|c|}
\hline $\begin{array}{l}\text { February } \\
2003\end{array}$ & $\begin{array}{l}\text { Lat. } \\
\left({ }^{\circ} \mathrm{S}\right)\end{array}$ & $\begin{array}{l}\text { Long. } \\
\left({ }^{\circ} \mathrm{W}\right)\end{array}$ & $\begin{array}{l}\text { Depth } \\
\text { range }(\mathrm{m})\end{array}$ & $\underset{\left(\mathrm{m}^{-3}\right)}{\text { Indiv }}$ & $\begin{array}{l}\text { iduals } \\
\qquad\left(\mathrm{m}^{-2}\right)\end{array}$ \\
\hline 13 & $\begin{array}{l}53.822 \\
53.822\end{array}$ & $\begin{array}{l}39.146 \\
39.146\end{array}$ & $\begin{array}{l}0-250 \\
250-0\end{array}$ & $\begin{array}{l}0.0162 \\
0.2465\end{array}$ & $\begin{array}{r}4.050 \\
61.625\end{array}$ \\
\hline 15 & $\begin{array}{l}53.803 \\
53.803 \\
53.719 \\
53.719\end{array}$ & $\begin{array}{l}38.529 \\
38.529 \\
37.971 \\
37.971\end{array}$ & $\begin{array}{l}0-180 \\
180-0 \\
0-150 \\
150-0\end{array}$ & $\begin{array}{l}0.1916 \\
0.3495 \\
3.6110 \\
0.1377\end{array}$ & $\begin{array}{r}34.488 \\
62.910 \\
541.650 \\
20.655\end{array}$ \\
\hline 16 & $\begin{array}{l}53.453 \\
53.453\end{array}$ & $\begin{array}{l}37.937 \\
37.937\end{array}$ & $\begin{array}{l}0-250 \\
250-0\end{array}$ & $\begin{array}{l}0.0671 \\
0.0278\end{array}$ & $\begin{array}{r}16.775 \\
6.950\end{array}$ \\
\hline Avg. & & & & 0.5809 & 93.638 \\
\hline
\end{tabular}

The software finds the best fit to a length-frequency distribution through iterating between a series of component types (normal, lognormal, exponential and gamma). The user must identify the expected number of components within the distribution before initialising the fitting procedure, which was performed by a quasi-Newton algorithm. No constraints were put on the proportions, the mean length and the variance expected in each component. The initial hypothesis based on other observations (Murphy \& Reid 2001) was that the South Georgia summer population contained 2 main components, with respective modal lengths of 40 and $55 \mathrm{~mm}$.

Reproductive development. We examined South Georgian krill taken at different times of the reproductive season in 3 different years (Fig. 1). The samples had been preserved in $10 \%$ buffered formalin since capture, a step that is necessary to give the ovary integrity during examination. Specimens were extracted randomly from the samples and measured for bodylength, $L$ (front of eye to tip of telson) and sexual stage following Morris et al. (1988) and Makarov \& Denys (1980). In all, 619 krill were analysed as above.

Ovarian analysis. All female specimens from the above samples were further categorised for sexual development stage ( $S D S$ ) according to the scale developed by Cuzin-Roudy \& Amsler (1991). The ovary was dissected and subsampled using a technique described in Cuzin-Roudy (2000) to determine the number of mature oocytes. Although formalin preservation affects the weight and size of specimens, this technique relies on relative rather than absolute measurements and so is not subject to bias. The measurements were made only on females at $S D S 7$, with an ovary completely filling the swollen carapace and extending into the 2nd abdominal segment, thus ensuring that no eggs had been lost to partial spawns. For each female, we measured (1) total body length, $L$ (mm), (2) total body wet weight, WWT (mg), (3) wet weight of dissected ovary, 
WWO (mg); (4) wet weight of sub-sample of ovary (mg). A fraction of the ovary $(1 / 10$ to $1 / 4)$ was sub-sampled and the number of mature oocytes counted. Multiplication by the inverse of the sub-sample fraction gave the total number of eggs in a batch (NMO). A full list of parameters is given in Table 2 .

Fecundity model. Spawning episode frequency: It is not possible to measure the frequency of spawning episodes directly because individuals cannot be tracked over time and experimental incubations are not adequate representations of in situ conditions. We approached this problem through modelling different scenarios based on the empirical information obtained by the present study. Our model focussed on the end of season samples taken in February 2003 since they can be used to assess the reproductive performance of each individual during the previous summer. The major premise of the model was the functional relationship between spawning and moult development in krill, described by Cuzin-Roudy \& Buchholz (1999, their Fig. 4). They proposed that reproductively active krill alternated between a vitellogenic moult cycle, during which the egg batch was built up, and a spawning moult cycle, during which eggs matured and were released during the premoult phase. We adopted the same model here, with 2 IMPs for 1 cycle of egg production, such that a spawning episode $(S)$ occurred in every other moult cycle at the premoult phase (i.e. from $1 / 2$ to $3 / 4$ of the way through the spawning moult cycle).

The first step was to determine when each krill finished spawning in the respective season; this depended on the $S D S$ of each individual in the end of season samples (13 to 17 February 2003). SDS 7 krill were assumed to be still spawning during the sampling date. Krill in $S D S 8$ were assumed to be $1 / 4$ of a moult cycle away from their last spawn given that the stage

Table 2. Euphausia superba. Parameters used in models

\begin{tabular}{|c|c|c|}
\hline Parametel & Description & Unit \\
\hline$\beta_{\text {egg }}$ & Daily exponential mortality rate of eggs & $\mathrm{d}^{-1}$ \\
\hline$\beta_{c a l}$ & Daily exponential mortality rate of nauplii and calyptopes & $\mathrm{d}^{-1}$ \\
\hline$\beta_{\text {furc }}$ & Daily exponential mortality rate of furcilia & $\mathrm{d}^{-1}$ \\
\hline $\begin{array}{l}\text { Cal day } \\
\text { day }\end{array}$ & $\begin{array}{l}\text { Predicted concentration of nauplii and calyptopes in water column on each day of the year } \\
\text { Day of year }\end{array}$ & $\mathrm{m}^{-2}$ \\
\hline$D$ & Length of reproductive season per krill & $\mathrm{d}$ \\
\hline e & Exponential function & \\
\hline$E$ & Annual fecundity rate & Eggs female ${ }^{-1} \mathrm{yr}^{-1}$ \\
\hline Eggs $_{d a y}$ & Predicted concentration of eggs in water column on each day of year & $\mathrm{m}^{-2}$ \\
\hline female & Mature female & \\
\hline F $\quad$ r & Function & \\
\hline Furc $_{\text {day }}$ & Predicted concentration of furcilia in water column on each day of year & $\mathrm{m}^{-2}$ \\
\hline$H$ & Initial estimate of previtellogenic period & $\mathrm{d}$ \\
\hline$H^{\prime}$ & Final estimate of previtellogenic period & $\mathrm{d}$ \\
\hline int & Integer value & \\
\hline I & Vitellogenic moult cycle period & d \\
\hline IMP & Inter-moult period & $\mathrm{d}$ \\
\hline$J$ & Spawning moult cycle period & $\mathrm{d}$ \\
\hline$L$ & Body length (front of eye to tip of telson) & $\mathrm{mm}$ \\
\hline$L_{\text {day }}$ & Body length on a specific day & $\mathrm{mm}$ \\
\hline $\mathrm{n}$ & An examined female & \\
\hline $\mathrm{N}$ & Total number of mature females examined & \\
\hline NMO & Number of mature oocytes/eggs in an ovary (a batch) & Eggs \\
\hline $\mathrm{NMO}_{s}$ & Number of mature oocytes/eggs spawned per spawning episode & Eggs \\
\hline$P$ & Probability of moult over $5 \mathrm{~d}$ period & \\
\hline$R$ & Residual days in reproductive season & $\mathrm{d}$ \\
\hline$S D S$ & Sexual development stage & \\
\hline$S$ & Spawning episode & \\
\hline$S_{\text {day }}$ & Day of year on which a spawning takes place & \\
\hline$T$ & Temperature & ${ }^{\circ} \mathrm{C}$ \\
\hline$U$ & Surface temperature & ${ }^{\circ} \mathrm{C}$ \\
\hline VSC & Cycles of egg production per year & $\mathrm{yr}^{-1}$ \\
\hline$V S C_{\max }$ & Upper limit to number of cycles of egg production $\mathrm{yr}^{-1}$ & $\mathrm{yr}^{-1}$ \\
\hline$W W T$ & Total body wet weight & $\mathrm{mg}$ \\
\hline$W W O$ & Wet weight of dissected ovary & $\mathrm{mg}$ \\
\hline$W$ & Concentration of reproductive females & ind. $\mathrm{m}^{-2}$ \\
\hline$z_{\text {day }}$ & Average number of eggs released per female on each day of reproductive season & Eggs female ${ }^{-1}$ \\
\hline$Z_{\text {day }}$ & Predicted concentration of eggs released by krill population on each day of reproductive season & Eggs $\mathrm{m}^{-2}$ \\
\hline
\end{tabular}


represents individuals that have recently spawned. Krill in SDS 9 and 10 have entered a stage of ovarian regression followed by reorganisation and therefore completed their terminal spawning episode some time previously. We assumed that $S D S 9$ krill had spawned 1 or 2 moult cycles before sampling and SDS 10 krill, 2 or 3 cycles before sampling. The precise number of cycles was varied stochastically for each krill in each model run.

The duration of the moult cycle (IMP) varied as a function of the prevailing surface temperature $(U)$ and the body length $(L)$, according to the algorithm provided by Tarling et al. (2006) for mature females. Surface temperature for each day of the productive season was determined through linear interpolations of conductivitytemperature-depth (CTD) profiles taken in the vicinity of South Georgia approximately 1 mo apart. Temperatures varied between $0.1^{\circ} \mathrm{C}$ in September and $3.2^{\circ} \mathrm{C}$ in February. Krill body length was predicted for each day $\left(L_{\text {day }}\right)$ through assuming a growth rate of $0.03 \mathrm{~mm} \mathrm{~d}^{-1}$ (Tarling et al. 2006) and working backwards from the date of sampling (i.e. 13 to 17 February). Calculations of IMP were carried out for adult females only:

where $I M P=\frac{5}{P}$

$$
P=\frac{\mathrm{e}^{2.00-0.057 L+0.1528 U-0.079 U^{2}}}{1+\mathrm{e}^{2.00-0.057 L+0.1528 U-0.079 U^{2}}}
$$

and $P$ is the probability of moult over a $5 \mathrm{~d}$ period.

Ovarian development begins with previtellogenesis, which is strongly linked to the onset of the first spring bloom (Cuzin-Roudy \& Labat 1992). The timing of spring blooms is variable in the South Georgia region but it is rare to find any earlier than mid-September (Atkinson et al. 2001). Therefore, we assumed that reproductive activity started around 15 September. A stochastic variance of $\pm 5 \mathrm{~d}$ around this date was included for each krill in each model run. From its starting point, the minimum duration of the previtellogenic period $(H)$ was set at 2 IMPs, after which the krill entered a vitellogenic moult cycle $(I)$, followed by a spawning moult cycle $(J)$. $I$ and $J$ both have durations of 1 IMP. The model was designed to calculate VSC, which is the number of cycles of egg production $(I+J)$ that a krill could fit within its reproductive season $(D)$.

$$
V S C=\operatorname{int}\left(\frac{D-H \pm 5}{I+J}\right)
$$

where int indicates an integer value. In many instances, there were extra days $(R)$ within the reproductive season that were insufficient for another cycle of egg production:

$$
R=D-V S C
$$

We assumed these extra days were part of the previtellogenic period and added them to $H$ to give a final estimate of the length of the previtellogenic period, $H^{\prime}$.
In the initial parameterisation of the model, krill were allowed to carry out a maximum of 3 cycles of egg production $\left(V S C_{\max }=3\right)$ with 3 spawning episodes $(S)$, based on the observations of Ross \& Quetin (1983). The procedure was performed 100 times on each krill to determine the variability between model runs. Further runs examined the sensitivity of model predictions to the initial parameterisations.

Eggs released per year: Ovarian analysis, described above, determined the number of mature eggs in a readyto-spawn ovary (NMO) as a function of body length $(L)$ :

$$
N M O=F(L)
$$

The body length of a krill each day $\left(L_{\text {day }}\right)$ varied over the course of the season according to the assumed growth rate $\left(0.03 \mathrm{~mm} \mathrm{~d}^{-1}\right) . L_{\text {day }}$ was applied to the function $F$ to determine the number of eggs released per spawning episode $(S)$. It is to be noted that the day of spawning $\left(S_{\text {day }}\right)$ varies between females according to the parameterisation above. Where there was more than 1 cycle of egg production per season, the total number of eggs released at each episode $\left(N M O_{s}\right)$ was summed to give an amount released per year, $E$ :

$$
E=\sum_{s=1}^{s=V S C} N M O_{s}
$$

$z_{\text {day }}$, the average number of eggs released per female on each day of the reproduction season was calculated as

$$
z_{\text {day }}=\frac{\sum_{\text {female }=1}^{\text {female }=N} N M O_{\text {female, }} S_{\text {day }} \text { day }}{N}
$$

The above equation indicates that when 'day' is equal to $S_{\text {day, }}$ Female $n$ releases $N M O$ eggs. $z_{\text {day }}$ was multiplied by the concentration of mature females in the water column $\left(W\right.$, ind. $\left.\mathrm{m}^{-2}\right)$ to give $Z_{\text {day, }}$ the predicted concentration of eggs released by the krill population on each day of the reproductive season (eggs $\mathrm{m}^{-2}$ ).

Embryo development model. The descent-ascent cycle of the embryos was simulated using a model developed by Hofmann \& Hüsrevolğlu (2003). The model determines the rate of sinking up to the point where the embryo hatches into a nauplius and subsequently calculates the time it would take the larvae to return to the surface. The rate of sinking was parameterised as a function of specific density of the water and the egg, and the rate of development as a function of temperature. Further details can be obtained from Hofmann \& Hüsrevolğlu (2003).

The main inputs into the model were CTD profiles taken in the vicinity of South Georgia, specifically temperature $\left(T,{ }^{\circ} \mathrm{C}\right)$ and ambient water density $(\sigma)$. To determine the degree of spatial variability, we ran the model with profiles taken from several locations cho- 
sen because (1) they were sites where gravid females were found and (2) they were geographically distant from each other and covered the range of environments occupied by krill around South Georgia (Fig. 1). To determine the degree of temporal variability, further runs were made using profiles taken in the same area at different times of year (November 2003, March 2004, December 2004).

Larval abundance model. It was necessary to determine both the rate of development and the rate of mortality to predict larval concentrations. Larval development rates were estimated through combining results from the above embryo development model with information from Mackintosh (1972) and Mauchline (1977) for late-stage larvae. Accordingly, the duration of different phases of development were as follows: egg development, $5 \mathrm{~d}$; nauplius to the end of calyptopes III, $35 \mathrm{~d}$; furcilia I to the end of furicilia VI, $60 \mathrm{~d}$. There are no direct estimates of mortality rates for Euphausia superba eggs and early-stage larvae. Therefore, we applied the equations of Hirst \& Kiørboe (2002) for copepods eggs and larvae, scaled to temperature of $4^{\circ} \mathrm{C}$. For eggs, this gave a daily exponential rate $\left(\beta_{\text {egg }}\right)$ of $0.19 \mathrm{~d}^{-1}$ and for nauplii and calyptopes $\left(\beta_{c a l}\right)$, $0.04 \mathrm{~d}^{-1}$. Brinton (1976) determined an exponential mortality rate of $1.0 \mathrm{mo}^{-1}$ for E. superba furcilia, which equates to a daily exponential rate of $0.034 \mathrm{~d}^{-1}\left(\beta_{\text {furc }}\right.$ ).

The predicted number of eggs residing in the water column each day $\left(E g g s_{d a y}\right)$ was determined as follows:

$$
\text { Eggs }_{\text {day }}=Z_{\text {day }-1} \mathrm{e}^{-\beta_{\text {egg }}}+Z_{\text {day }}-Z_{\text {day }-5} \mathrm{e}^{-5 \cdot \beta_{\text {egg }}}
$$

where the first term refers to the resident population of eggs, the second, to the newly spawned (recruiting) eggs and the third, to the eggs developing into nauplii.

The number of nauplii and calyptopes occurring on each day of the year $\left(\mathrm{Cal}_{\text {day }}\right)$ was calculated in a similar fashion:

$\mathrm{Cal}_{\text {day }}=$

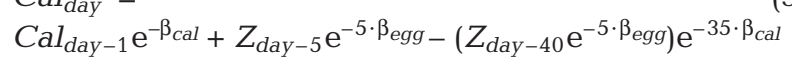

The following was used to estimate the concentration of furcilia on each day of the year:

Furc $_{\text {day }}=$ Furc $_{\text {day }-1} \mathrm{e}^{-\beta_{\text {furc }}}+\left(Z_{\text {day }-40} \mathrm{e}^{\left.-5 \cdot \beta_{\text {egg }}\right)} \mathrm{e}^{-35 \cdot \beta_{c a l}-}\right.$

$\left[\left(Z_{\text {day }-100} \mathrm{e}^{\left.-5 \cdot \beta_{\text {egg }}\right)} \mathrm{e}^{-35 \cdot \beta_{c a l}}\right] \mathrm{e}^{-60 \cdot \beta_{\text {furc }}}\right.$

Larval advection model. The spatial extent of successful development was examined through seeding a $400 \mathrm{~km}$ grid around South Georgia with model particles that performed descent-ascent cycles followed by diel vertical migrations (DVM) between 0 and $350 \mathrm{~m}$ for the first feeding stages (Fraser 1936). Further sensitivity runs examined the effect of decreasing this DVM depth range. The vertical movement of the particles was sinusoidal with a $24 \mathrm{~h}$ wavelength, reaching the deepest extent $(350 \mathrm{~m})$ at midday and the surface at midnight. Particles were moved vertically at each timestep $(\Delta t=1 \mathrm{~h})$ according to the egg development cycle and diel vertical migration scheme and were subject to horizontal advection within the current flow at their given depth. A second order Runge-Kutta advection scheme was used to predict the horizontal movement of the eggs and larvae, following Murphy et al. (2004). The horizontal velocity fields were provided by the 'Ocean Circulation and Climate Advanced Modelling' project model (OCCAM; Webb \& de Cuevas 2003, D. J. Webb et al. unpubl. data). OCCAM is a global numerical ocean general circulation model with a horizontal resolution of $0.25^{\circ} \times 0.25^{\circ}$ and 36 levels in the vertical, and has been forced with time-varying winds. Monthly output from the period 1993 to 2000 was averaged to produce climatological monthly velocity fields and the surface model velocity field was replaced with an average of the velocities from the top 2 model levels to produce a more realistic surface circulation. Prior to use in the advection scheme, these mean fields were modified following Killworth (1996) to avoid errors associated with linear interpolation between mean velocity fields. Velocities from the nearest model level to the depth of the particle at each timestep were used.

Seeding points were distributed on a regular $0.25^{\circ}$ latitude $\times 0.5^{\circ}$ longitude grid, giving a total of 175 release points. A no-slip boundary condition was implemented at the South Georgia coast and any egg encountering the bottom was assumed not to complete the cycle, taking no further part in the simulations. The 3D particle trajectories were simulated for $60 \mathrm{~d}$, which covers the developmental period from egg to midstage furcilia in the South Georgia region (Mackintosh 1972). Model runs were made at different times of the reproductive season using the predicted descentascent cycles and OCCAM outputs for those periods.

Larval surveys. Net-sample surveys for krill larvae were carried out in the vicinity of South Georgia in January/February 2000, January 2002 and February 2003. Bongo nets were deployed between 0 and $200 \mathrm{~m}$ with 100 and $200 \mu \mathrm{m}$ mesh nets. Samples were examined for all stages of krill larvae (nauplius to Furcilia VI).

\section{RESULTS}

\section{Post-larval population structure}

We found 2 principal modes in the adult population in February 2003, with modal lengths of around $44 \mathrm{~mm}$ in one and $53 \mathrm{~mm}$ in the other (Fig. 2). Juvenile and subadults dominated the first mode while adults dominated the second. According to the growth curves of Mackintosh (1972) for the South Georgia region, 40 to $45 \mathrm{~mm}$ krill around South Georgia would be around 


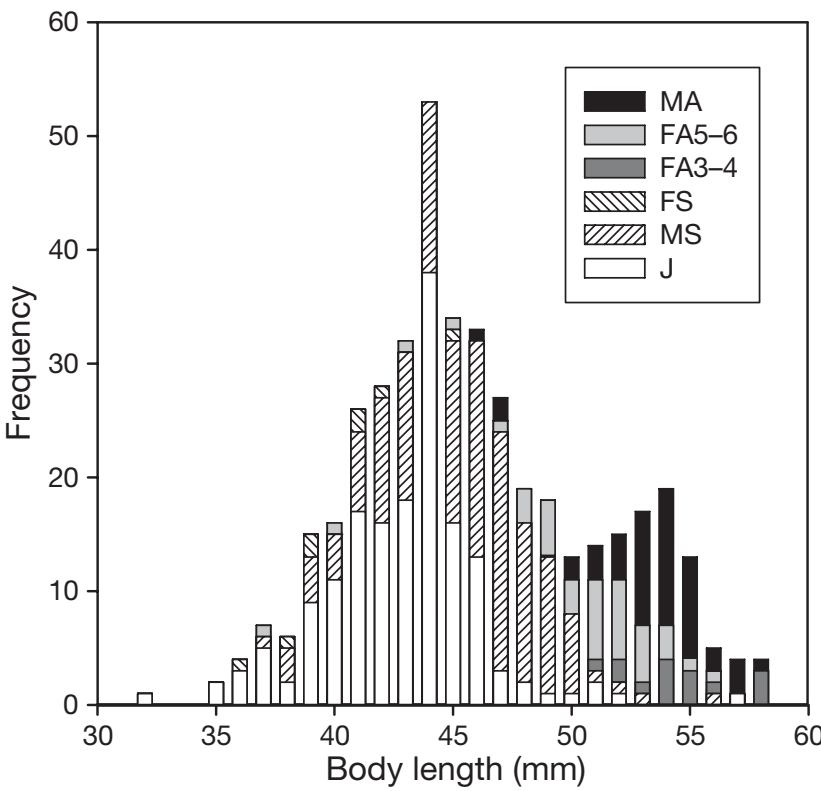

Fig. 2. Euphausia superba. Length-frequency distribution of krill at South Georgia in February 2003, stacked according to maturity stage (Morris et al. 1988). MA: male adult; FA5-6: a spawning or postspawn female adult; FA3-4: female adult with no external signs of imminent spawning activity; FS: female subadult; MS: male subadult; J: juvenile

24 mo old, having over-wintered twice (2+) while those above $50 \mathrm{~mm}$ would be more than 36 mo old, having over-wintered 3 times (3+). Accordingly, we assumed that the first mode represented a $2+$ cohort and the second mode, a $3+$ (or older) cohort. There was no evidence of a cohort of 12 to 14 mo old (1+) individuals in any of the samples.

Overall, most krill in the population were either juvenile $(38 \%)$ or subadult $(37 \%)$, with both types being particularly dominant in the $2+$ cohort. Mature females were more common in the $3+$ cohort and made up $13 \%$ of the entire population. Mature males, which comprised $12 \%$ of the population, were also mainly $3+$ individuals.

The concentration of adult krill in net-catches was around 0.6 ind. $\mathrm{m}^{-3}$ (Table 1), although the difference between the largest and smallest catches differed by over 2 orders of magnitude (max. 3.6 ind. $\mathrm{m}^{-3}$; min. 0.02 ind $\mathrm{m}^{-3}$ ). Depth-integrated concentrations were similarly variable, with the average being 93.64 ind. $\mathrm{m}^{-2}$.

\section{Reproductive development}

Female krill were already reproductively active in December (1996), with $80 \%$ females in vitellogenesis $(S D S 4,5,6)$ and $8 \%$ ready to spawn (SDS 7, Table 3$)$. The population was more advanced in January (2002), with $43 \%$ spawning krill (SDS 7) or recently postspawn ( $S D S$ 8) krill. Krill with immature ovaries (SDS 1 and 2) were apparent in the February (2003) samples, making up $17 \%$ of the population. Of the remainder, $23 \%$ were either spawning or had recently spawned (SDS 7 and 8 respectively) and $52 \%$ were spent (SDS 9 and 10). None of the females in the February samples contained a stock of previtellogenic oocytes, which indicates no further spawning would occur beyond that date.

\section{Ovarian analysis}

The NMO within an egg-batch was positively and significantly related to $L$. This allowed a precise functional form for Eq. 5 (above) to be defined:

$$
\begin{gathered}
\log (N M O)=4.55 \log (L)-3.88 \\
\left(F_{28}=21.04, \mathrm{p}<0.0001 ; \mathrm{r}^{2}=0.429\right)
\end{gathered}
$$

On average, ready-to-spawn ovaries made up $43 \%$ of the total wet weight of the krill (WWT, Table 4). The smallest females $(43.8 \mathrm{~mm})$ contained 5590 mature oocytes, the largest female $(57.9 \mathrm{~mm}), 16000$ mature oocytes.

\section{Fecundity model}

Spawning episode frequency. The model predicted that $11 \%$ of krill (SD 3\%) completed 1 spawning episode per season, $60 \%$ (SD 5\%) 2 spawning episodes and $29 \%$ (SD $3 \%$ ) 3 spawning episodes (Fig. 3).

Table 3. Euphausia superba. Left: percentage of females at various sexual development stages (SDS) during summer at South Georgia; Right: percentage in different phases of ovarian development. Imm. (immature): SDS $1+2$; Prev. (previtellogenesis): $S D S 3+4$; Vit. (vitellogenesis): $S D S 5+6$; Sp. (spawning): $S D S 7+8$; Rest. (resting): $S D S 9+10$. Mode of the population progresses from being principally previtellogenic in December (1996) to spawning in January (2002) and resting in Feburary (2003).

\begin{tabular}{|c|c|c|c|c|c|c|c|c|c|c|c|c|c|c|c|c|}
\hline \multirow{2}{*}{$\begin{array}{l}\text { Sample date } \\
\text { (d/mo/yr) }\end{array}$} & \multirow[t]{2}{*}{$N$} & \multicolumn{10}{|c|}{$-\operatorname{SDS}(\%)$} & \multicolumn{5}{|c|}{ Ovarian phase $(\%)$} \\
\hline & & 1 & 2 & 3 & 4 & 5 & 6 & 7 & 8 & 9 & 10 & Imm. & Prev. & Vit. & Sp. & Rest. \\
\hline $31 / 12 / 96$ & 40 & 0 & 7 & 5 & 68 & 5 & 7 & 7 & 0 & 0 & 0 & 7 & 73 & 12 & 7 & 0 \\
\hline 26/01/02 & 7 & 14 & 43 & 0 & 0 & 0 & 0 & 29 & 14 & 0 & 0 & 57 & 0 & 0 & 43 & 0 \\
\hline $13-17 / 02 / 03$ & 65 & 5 & 12 & 0 & 0 & 0 & 0 & 23 & 8 & 45 & 7 & 17 & 0 & 0 & 31 & 52 \\
\hline
\end{tabular}
Spawning was observed to various extents in all 3 months 


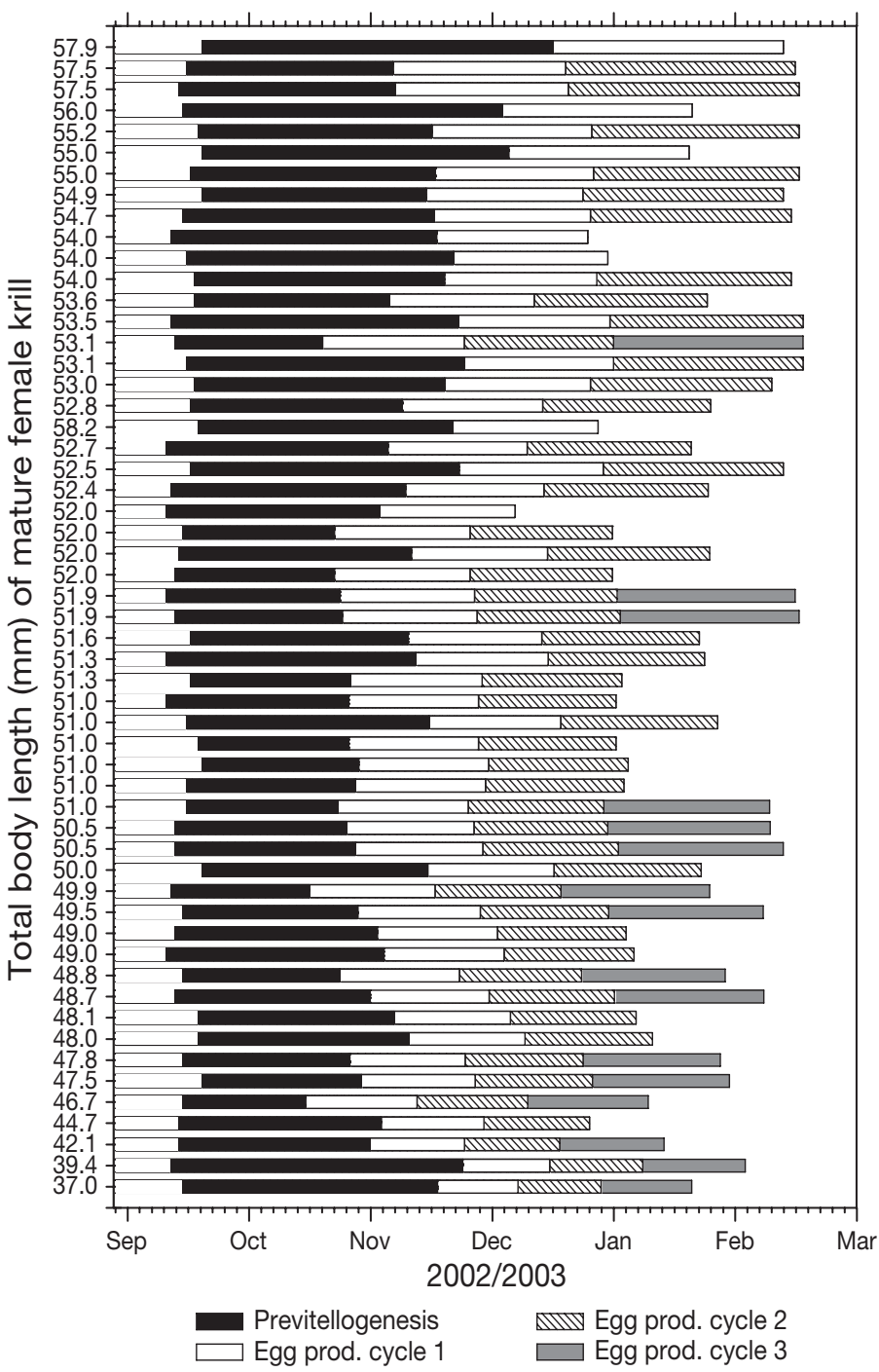

Fig. 3. Euphausia superba. Predicted durations of previtellogenesis $\left(H^{\prime}\right)$ and egg production $(I+J)$ of 55 krill according to development of their ovaries. The data presented is for 1 example run. This was combined with 99 further runs to derive the average pattern detailed in the top row of Table 5. Note that actual dates of spawning $\left(S_{\text {day }}\right)$ are at the right hand end of respective egg production cycle bar

On average, the smallest krill were predicted to achieve the highest spawn frequencies, since their $I M P$ s were the shortest. The average period between spawning episodes was $36 \mathrm{~d}$ (SD $7 \mathrm{~d}$ ), with some krill taking as little as $20 \mathrm{~d}$ and others up to $58 \mathrm{~d}$. Previtellogenesis lasted an average of $53 \mathrm{~d}$ (SD $12 \mathrm{~d}$ ), although some of the smallest krill completed previtellogenesis in $31 \mathrm{~d}$. Spawning started in late November and the majority of krill were predicted to complete their first spawn by late December. A second spawning episode mostly occurred around mid- to late January. The small proportion of krill that managed a third spawning episode did so between mid-January and mid-
February. When there was more than 1 spawning episode per season, the average intervening period between episodes was $78 \mathrm{~d}$.

Eggs released per year. The model predicted that a female krill produced an average of 12343 eggs $\mathrm{yr}^{-1}$, mostly over 2 spawning episodes. Many of the krill that only achieved 1 spawning episode per year were amongst the largest individuals within the sample, while those that spawned 3 times were amongst the smallest (Fig. 4). Despite such differences in spawning frequency, some of the larger krill were predicted to release as many eggs in 2 spawning episodes as the smaller krill released in 3.

Eggs released on each day of year: This parameter $\left(Z_{\text {day }}\right)$ was the product of the average number of eggs released female ${ }^{-1} \mathrm{~d}^{-1}\left(z_{\text {day }}\right)$ and the average concentration of mature females $\left(W\right.$, ind. $\left.\mathrm{m}^{-2}\right)$. The former oscil-

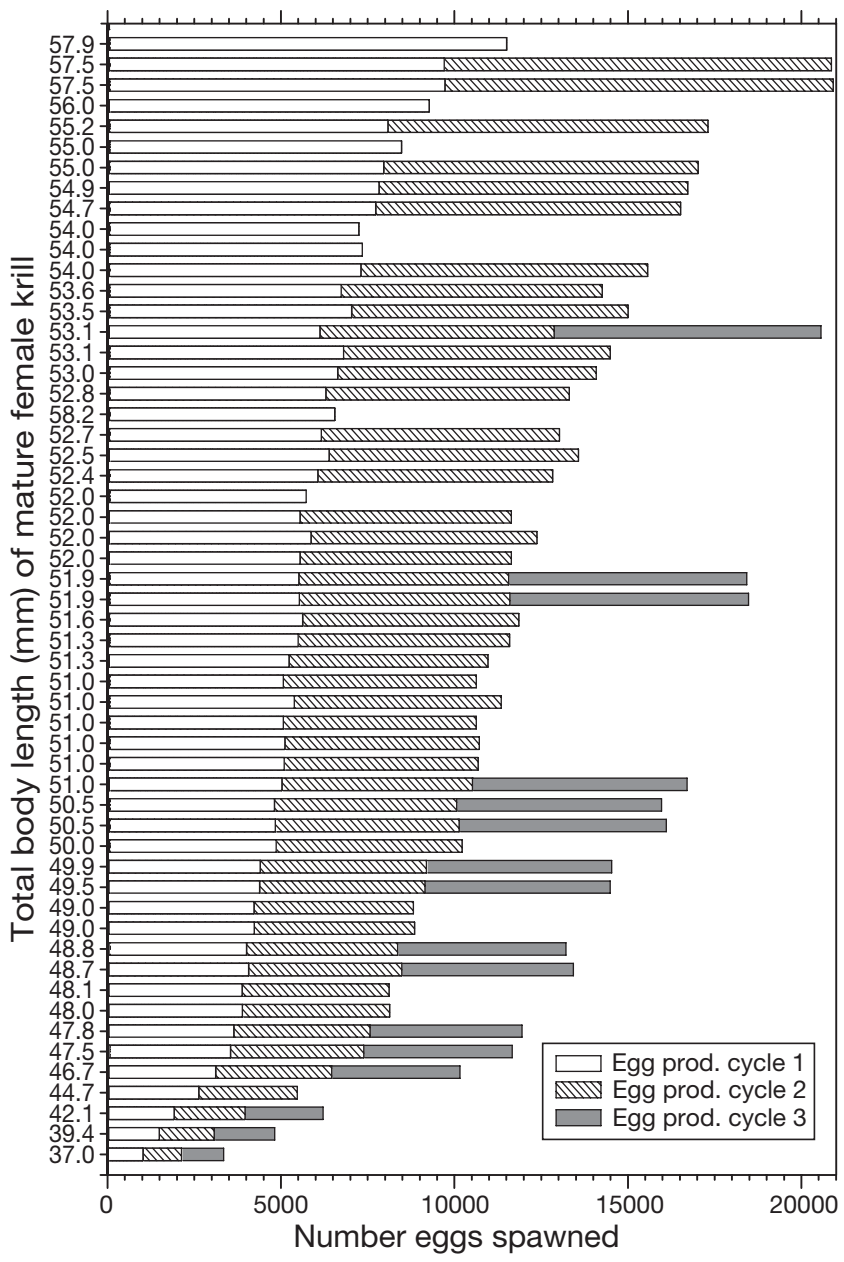

Fig. 4. Euphausia superba. Annual fecundity rate ( $E_{1}$ eggs female ${ }^{-1} \mathrm{yr}^{-1}$ ) of 55 krill caught around South Georgia in February 2003. Data is for 1 example run; this was combined with 99 further runs to derive average pattern in top row of Table 5. Annual fecundity rate is the sum of all egg production bars for each respective individual 
Table 4. Euphausia superba. Characteristics of 27 'ready-tospawn' (SDS 7) females analysed for egg-batch size, sampled around South Georgia in December 1996, January 2002 and February 2003. N: body length; $W W T$ : total wet weight; WWO: total ovarian body wet weight; NMO: total number of mature oocytes (oc3 and oc4) in ovary

\begin{tabular}{|lccc|}
\hline Characteristic & Range & Mean & SE \\
\hline $\mathrm{N}(\mathrm{mm})$ & $43.8-57.9$ & 52.7 & 0.6 \\
$W W T(\mathrm{mg})$ & $1284.6-2012.5$ & 1696.7 & 70.7 \\
$W W O(\mathrm{mg})$ & $385.1-1229.1$ & 731.4 & 38.5 \\
NMO & $5590-16030$ & 10320 & 530.00 \\
\hline
\end{tabular}

lated between 0 and 820 eggs $\mathrm{d}^{-1}$. Multiplying the average concentration of adult krill in nets (93.64 ind. $\mathrm{m}^{-2}$ ) by the percentage of mature females $(13 \%)$ determined the latter to be 12.17 ind. $\mathrm{m}^{-2}$. Accordingly, between 0 and 26000 eggs $\mathrm{m}^{-2}$ were produced by the krill population during the reproductive season (Fig. 5).

Sensitivity analyses. One of the major assumptions of the fecundity model was the starting date of pre-

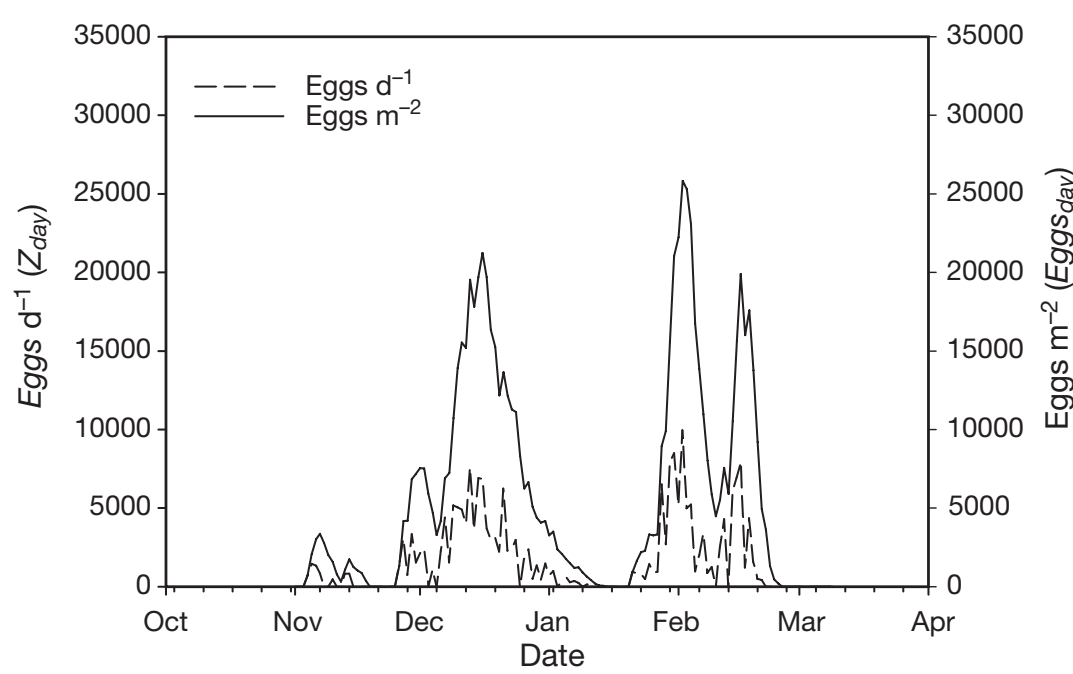

Fig. 5. Euphausia superba. Predicted concentration of eggs released by the krill population $\left(Z_{d a y}\right.$ dashed line) and the concentration residing in the water column (Eggs day, $_{\text {, }}$ solid line) on each day of the productive season vitellogenesis, which was set at the time that the first blooms were observed around South Georgia. It is likely that there will be some interannual variance and spatial variance in bloom conditions. The starting day was altered by $-20 \mathrm{~d},+20 \mathrm{~d}$ and $+40 \mathrm{~d}$ (Table 5 , Tests 1 , 2 and 3 respectively). Making the start day earlier by $20 \mathrm{~d}$ increased the VSC by around 0.5 , while delaying the start day decreased VSC by a similar amount. The corresponding amount of eggs released $\mathrm{yr}^{-1}(E)$ were increased and decreased by around 2000 respectively. A $40 \mathrm{~d}$ delay meant that most individuals missed a complete spawning episode, resulting in $E$ being halved.

The model of Cuzin-Roudy \& Buchholz (1999) proposed that a spawning cycle $(J)$ always followed a vitellogenic cycle $(I)$, where both $I$ and $J$ lasted for 1 IMP each. However, in poor feeding conditions, it is possible that Imay last for $2 I M P$ s or more, as vitellogenesis may be retarded. Making $I$ last 2 IMPs (Table 5, Test 4) more than halved VSC, whilst $E$ decreased by $40 \%$.

It has been observed that krill with regressed or reorganised ovaries $(S D S$ 9 and 10) switch to a lengthened IMP (Quetin et al. 2003). Accordingly, IMPs of krill in SDS 9 and 10 at time of sampling were increased by $50 \%$ relative to those set in the original model run. This decreased $V S C$ and $E$ by only a small amount (Table 5, Test 5).

We placed an upper limit of 3 spawning episodes per year $\left(V S C_{\max }=3\right)$ in the initial model run. It was clear in Fig. 3 that some of the smaller krill were capable of more. In fact, these krill could achieve a VSC of 5 when the restriction was lifted. However, this only had a small effect on the average $V S C$ and $E$ of the population because these individuals were a minor fraction of the population (Table 5, Test 6).

Table 5. Euphausia superba. Effect of altering parameterisation of fecundity model on average (SD) number of spawning episodes and number of eggs released $\mathrm{yr}^{-1}$ by a typical population around South Georgia

\begin{tabular}{llrr}
\hline $\begin{array}{l}\text { Test } \\
\text { no. }\end{array}$ & Sensitivity test & $\begin{array}{c}\text { Average } \\
\text { spawns } \mathrm{yr}^{-1}(V S C)\end{array}$ & $\begin{array}{c}\text { Average annual no. of eggs } \\
\text { released } \mathrm{krill}^{-1} \mathrm{yr}^{-1}(E)\end{array}$ \\
\hline $\begin{array}{l}\text { Best estimate } \\
1\end{array}$ & Initial runs: $I+J=2$ IMP & $2.18(0.61)$ & $12343(232)$ \\
2 & Previtellogenesis period began 20 d earlier & $2.64(0.52)$ & $14923(168)$ \\
3 & Previtellogenesis period began 20 d later & $1.64(0.58)$ & $9413(199)$ \\
4 & Previtellogenesis period began 40 d later & $1.18(0.44)$ & $6878(217)$ \\
5 & $I=2$ IMP, J = 1 IMP & $1.29(0.52)$ & $7327(126)$ \\
6 & $I M P$ in $S D S 9$ and 10 is 50\% longer & $1.95(0.71)$ & $11066(247)$ \\
\end{tabular}




\section{Embryo development model}

The depth-time trajectories predicted by the embryo developmental model were a function of temperature and water density profiles. We used the profiles taken at 6 different stations where gravid females were found in February 2003 (Fig. 6). Each profile consistently showed the presence of 3 major bodies of water: Antarctic Surface Water (AASW) above $80 \mathrm{~m}$, Winter Water (WW) around $150 \mathrm{~m}$ and Circumpolar Deep Water (CDW) deeper than $200 \mathrm{~m}$. Profiles varied by around $\pm 0.5^{\circ} \mathrm{C}$ at most depths. During February, the AASW was at its warmest whilst the temperature minimum in the WW was mid-way between that observed in November and that in March (Fig. 7). The variability in CDW at different times of year was relatively small.

In February 2003, the hatching depths of the sinking eggs in the different localities of our study swere very

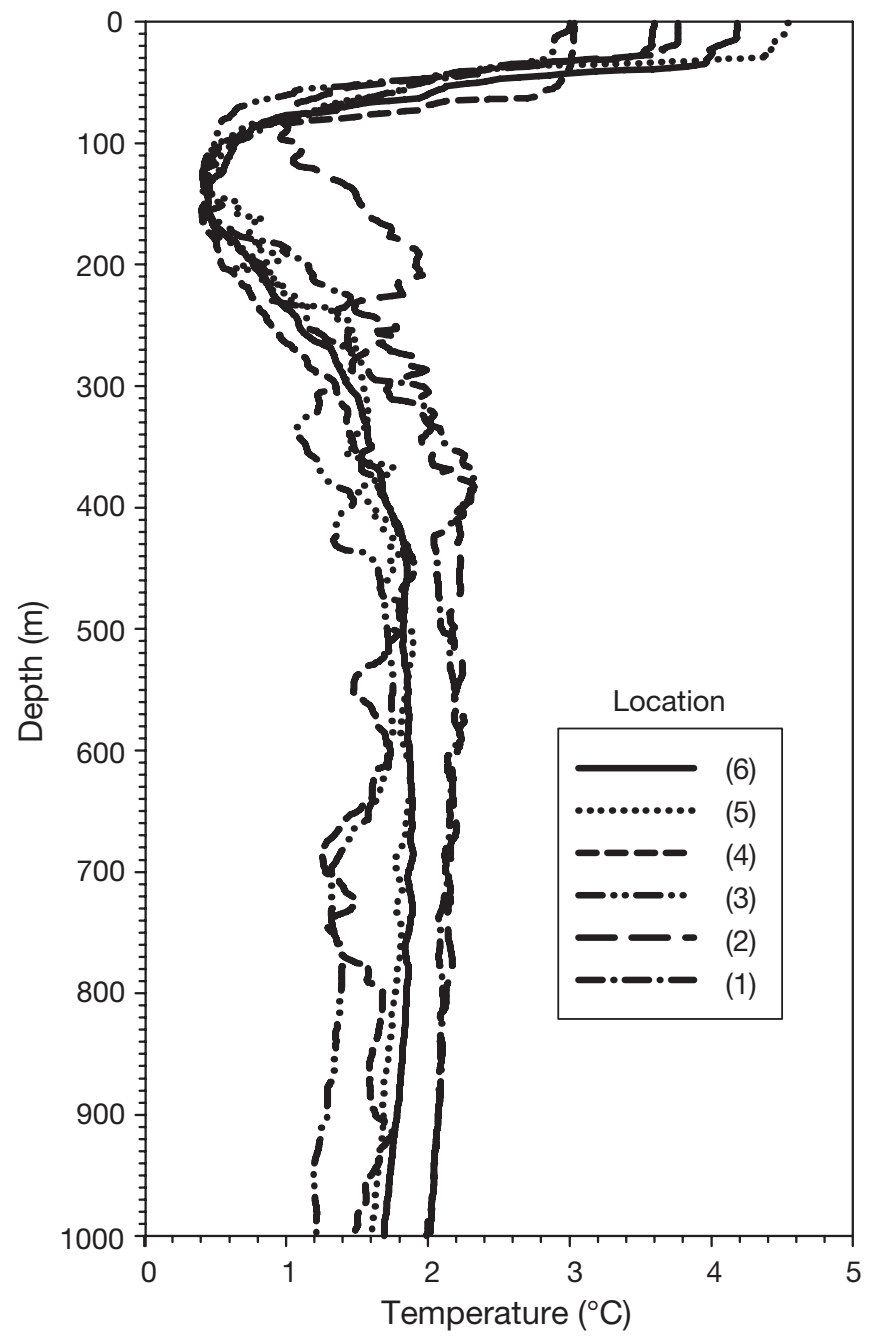

Fig. 6. Euphausia superba. Temperature-depth profiles at 6 locations in the vicinity of South Georgia during February 2003. Numbers in legend refer to locations marked in Fig. 1 similar, ranging between 490 and $511 \mathrm{~m}$ (Table 6). It took approximately $5 \mathrm{~d}$ to reach this point in all instances. Reascent took another 7 to $8 \mathrm{~d}$ and all larvae had reached the surface by Day 13 either as a late-stage metanauplius or a recently moulted 1st calyptopis. By this point the larvae had used just $8 \%$ of their carbon resource, which is well within their tolerance limits. A similar descent-re-ascent profile was predicted for other times of year also (Table 6, Fig. 8). The eggs sank deepest in March, reaching around $520 \mathrm{~m}$. However, the higher temperatures made the re-ascent relatively fast and the ascent time was the same as in February, despite the greater vertical distance covered. In November, the eggs sank to only $480 \mathrm{~m}$ before hatching but the cold temperatures made their re-ascent relatively slow and they did not reach the surface until Day 14. Despite this, they used just $9 \%$ of their carbon resource in making the journey, well within tolerable limits.

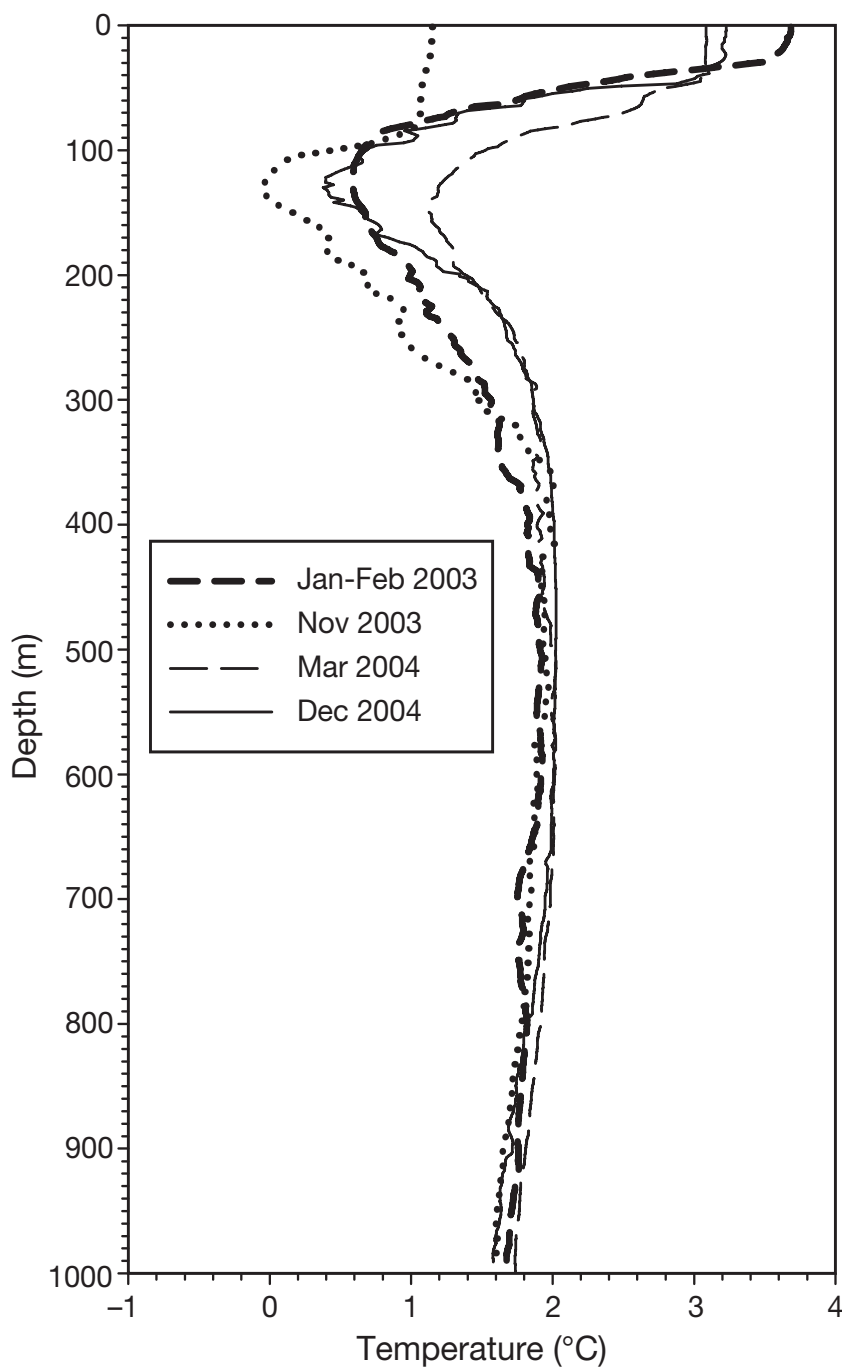

Fig. 7. Euphausia superba. Typical temperature-depth profiles at different times of reproductive season around South Georgia 
Table 6. Euphausia superba. Predicted descent-ascent trajectories of eggs and early development stages at South Georgia illustrating effect of location on trajectories (Columns 2-7) and typical trajectories for other times of year. (Columns 8-10). Numbers in parentheses: Locations 1-6 in Fig. 1. mn: metanauplius; CI: calyptopis I

\begin{tabular}{|c|c|c|c|c|c|c|c|c|c|}
\hline & $\begin{array}{l}30 \mathrm{Jan} \\
2003(1)\end{array}$ & $\begin{array}{l}31 \text { Jan } \\
2003(2)\end{array}$ & $\begin{array}{c}9 \text { Feb } \\
2003(3)\end{array}$ & $\begin{array}{c}9 \text { Feb } \\
2003(4)\end{array}$ & $\begin{array}{l}14 \mathrm{Feb} \\
2003(5)\end{array}$ & $\begin{array}{l}16 \text { Feb } \\
2003(6)\end{array}$ & $\begin{array}{l}\text { Nov } \\
2003\end{array}$ & $\begin{array}{c}\text { Dec } \\
2004\end{array}$ & $\begin{array}{l}\text { Mar } \\
2004\end{array}$ \\
\hline Location & $\begin{array}{l}54.099^{\circ} \mathrm{S} \\
40.984^{\circ} \mathrm{W}\end{array}$ & $\begin{array}{l}54.910^{\circ} \mathrm{S} \\
39.985^{\circ} \mathrm{W}\end{array}$ & $\begin{array}{l}56.119^{\circ} \mathrm{S} \\
33.073^{\circ} \mathrm{W}\end{array}$ & $\begin{array}{l}55.451^{\circ} \mathrm{S} \\
34.389^{\circ} \mathrm{W}\end{array}$ & $\begin{array}{l}53.432^{\circ} \mathrm{S} \\
38.696^{\circ} \mathrm{W}\end{array}$ & $\begin{array}{l}53.468^{\circ} \mathrm{S} \\
38050^{\circ} \mathrm{W}\end{array}$ & $\begin{array}{l}\text { South } \\
\text { Georgia }\end{array}$ & $\begin{array}{l}\text { South } \\
\text { Georgia }\end{array}$ & $\begin{array}{l}\text { South } \\
\text { Georgia }\end{array}$ \\
\hline Depth of hatching (m) & 491.00 & 505.36 & 507.64 & 490.22 & 510.74 & 501.30 & 491.20 & 501.00 & 516.33 \\
\hline Time until hatching (d) & 4.71 & 4.71 & 4.96 & 4.88 & 4.88 & 4.88 & 4.80 & 4.75 & 4.79 \\
\hline $\begin{array}{l}\text { Total time for descent } \\
\text { and re-ascent (d) }\end{array}$ & 11.63 & 11.50 & 12.54 & 12.04 & 12.21 & 12.08 & 12.15 & 11.70 & 11.75 \\
\hline $\begin{array}{l}\text { Time between hatching } \\
\text { and resurfacing (d) }\end{array}$ & 6.92 & 6.79 & 7.58 & 7.17 & 7.33 & 7.21 & 7.35 & 6.95 & 6.96 \\
\hline$\%$ carbon stores remaining & 92.27 & 92.40 & 91.25 & 91.85 & 91.58 & 91.77 & 91.78 & 92.13 & 92.16 \\
\hline Time to end of mn & 11.79 & 11.67 & 12.08 & 12.00 & 11.96 & 11.96 & 12.03 & 11.83 & 11.79 \\
\hline Time to end of CI & 27.21 & 27.08 & 27.63 & 27.54 & 27.29 & 27.33 & 29.15 & 27.33 & 27.31 \\
\hline Stage on reaching surface & $\mathrm{mn}$ & $\mathrm{mn}$ & CI & $\mathrm{mn} / \mathrm{CI}$ & CI & CI & CI & $\mathrm{mn}$ & $\mathrm{mn} / \mathrm{CI}$ \\
\hline Mean temp $\left({ }^{\circ} \mathrm{C}, 0-500 \mathrm{~m}\right)$ & 1.69 & 1.94 & 1.24 & 1.41 & 1.52 & 1.52 & 1.22 & 1.72 & 1.88 \\
\hline
\end{tabular}

Over $80 \%$ of locations within a $400 \mathrm{~km}$ grid surrounding South Georgia were suitable for the successful completion of the descent-ascent cycle (Table 7 ). Most of the unsuitable seeding points were within the $500 \mathrm{~m}$ isobath, although under the effect of offshore advection some of these shallow areas became suitable (Fig. 9). Around $30 \%$ of the larvae remained within the $400 \mathrm{~km}$ grid at the end of $60 \mathrm{~d}$. The majority of those that had left the boundaries moved

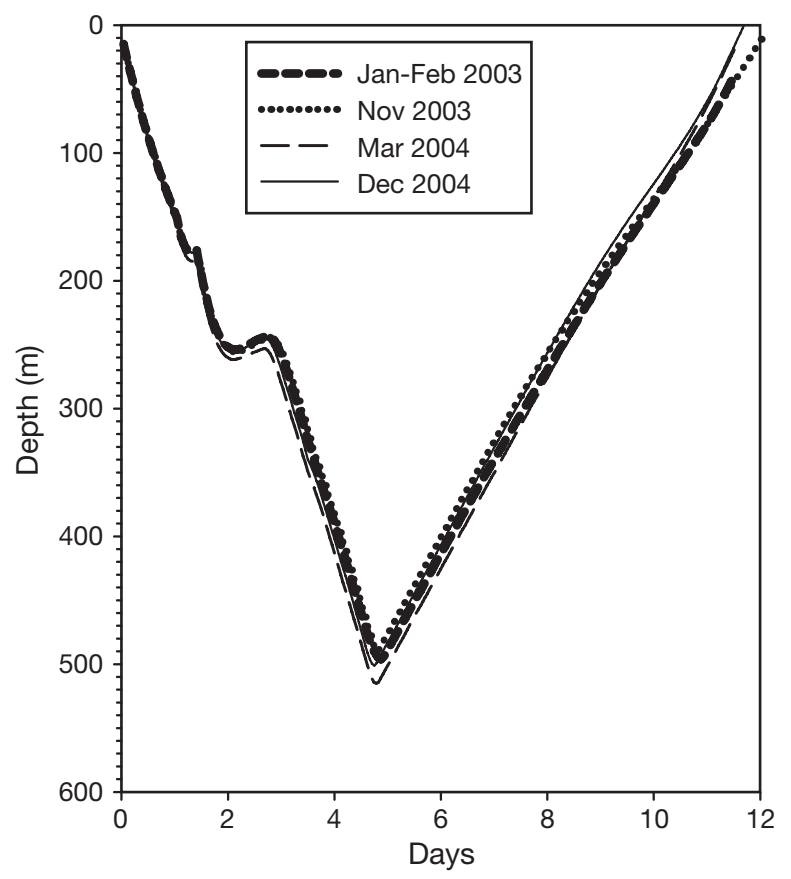

Fig. 8. Euphausia superba. Depth-time trajectories of descent of eggs and re-ascent of larvae predicted for different times of reproductive season around South Georgia. Days: no. of days after release of eggs either westwards or northwards (Fig. 10). Most expatriates were still within $100 \mathrm{~km}$ of the grid boundary after $60 \mathrm{~d}$. Decreasing the DVM depth range of the larvae made virtually no difference to these results.

\section{Larval abundance model}

There were peaks and troughs in the concentration of eggs and larvae in the water column over the course of the reproductive season (Figs. $5 \& 11$ ). With respect to eggs, the model predicted 2 major peaks in their concentration, the first in mid-December in which there were up to $21000 \mathrm{~m}^{-2}$ and the second at the beginning of February, where a maximum of $26000 \mathrm{~m}^{-2}$ were predicted. A similar pattern was seen in the abundance of the nauplii and calyptopes which

Table 7. Euphausia superba. Fate of model eggs/larvae advected by prevailing currents predicted by OCCAM; 175 eggs were released every $0.25^{\circ}$ latitude $\times 0.5^{\circ}$ longitude in a $400 \mathrm{~km}$ grid surrounding South Georgia and followed descent-ascent trajectory predicted for that time of year. On reaching the surface, larvae performed a diel vertical migration between 0 and $350 \mathrm{~m}$ (Fraser 1936). Also shown are number and \% of larvae remaining in the grid after $60 \mathrm{~d}$

\begin{tabular}{|c|c|c|c|c|}
\hline \multirow[t]{2}{*}{$\begin{array}{l}\text { Starting } \\
\text { date }\end{array}$} & \multicolumn{2}{|c|}{$\begin{array}{c}\text { Alive after } \\
\text { descent-ascent cycle }\end{array}$} & \multicolumn{2}{|c|}{$\begin{array}{l}\text { Within grid } \\
\text { after } 60 \mathrm{~d}\end{array}$} \\
\hline & No. & $\%$ & No. & $\%$ \\
\hline $1 \mathrm{Nov}$ & 143 & 81.7 & 53 & 30.3 \\
\hline $1 \mathrm{Dec}$ & 145 & 82.9 & 57 & 32.6 \\
\hline $1 \mathrm{Jan}$ & 145 & 82.9 & 59 & 33.7 \\
\hline $1 \mathrm{Feb}$ & 146 & 83.4 & 56 & 32.0 \\
\hline $1 \mathrm{Mar}$ & 145 & 82.9 & 54 & 30.9 \\
\hline
\end{tabular}




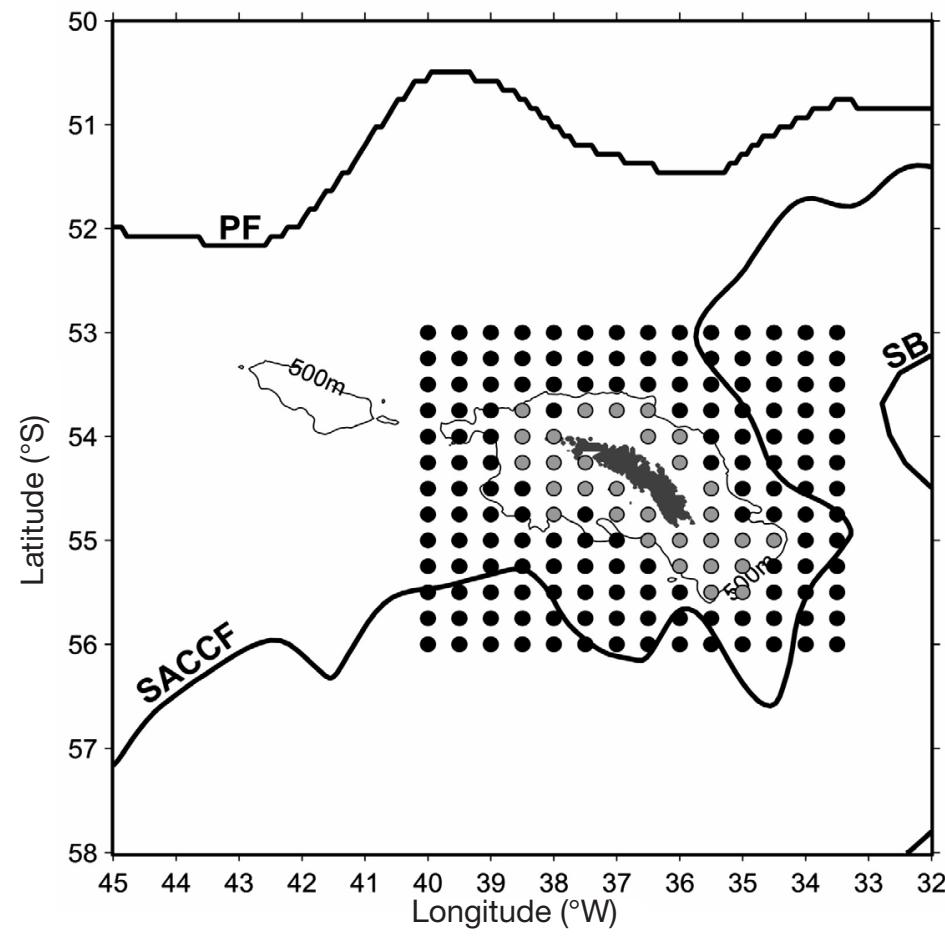

Fig. 9. Euphausia superba. Predicted distribution of successful (•) and unsuccessful (O) larval development within a 400 by $400 \mathrm{~km}$ region around South Georgia. Fronts are marked as in Fig. 1

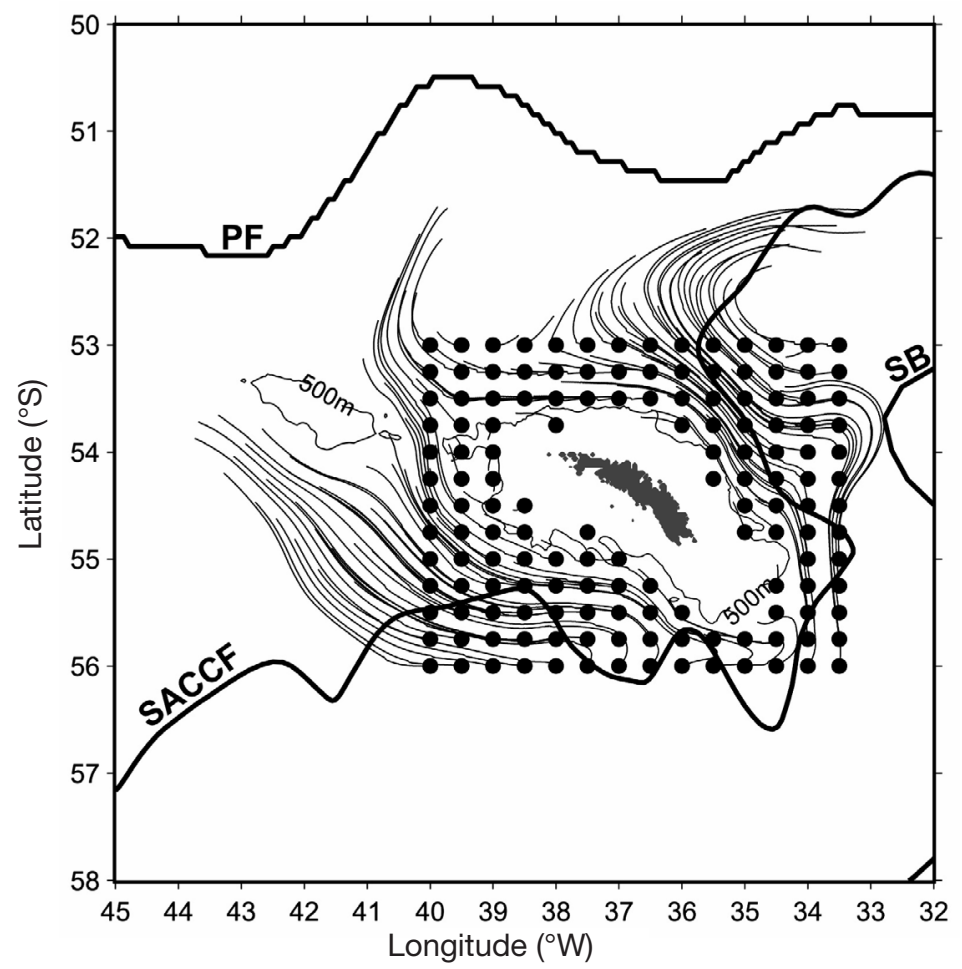

Fig. 10. Euphausia superba. Predicted horizontal displacement of model eggs/larvae $60 \mathrm{~d}$ after being spawned. Calculated trajectories (thin lines) are added to points where descent-ascent cycle is completed successfully $(\bullet)$. Fronts as in Fig. 1 peaked in early January $\left(22000 \mathrm{~m}^{-2}\right)$ and late February $\left(16000 \mathrm{~m}^{-2}\right)$. Furcilia began to increase in numbers from January onwards, reaching a relatively stable population of between 3000 and $6000 \mathrm{~m}^{-2}$ in late summer and autumn.

\section{Observed early-stage larval abundance}

Krill larvae (calyptopes and furcilia) were caught within a $400 \mathrm{~km}$ radius of South Georgia in the summers of 2000, 2002 and 2003 (Fig. 12). Where they occurred, abundances were generally in the range of 100 to 1000 larvae $\mathrm{m}^{-2}$, although concentrations as high as 50814 larvae $\mathrm{m}^{-2}$ were observed in 2001 (Table 8). The distribution of larvae in all 3 yr was patchy, with larvae being absent from more than half of all net catches in the region. The most intensive survey was carried out in 2002, with 59 samples taken within a $200 \mathrm{~km}$ radius of South Georgia, covering both on-shelf and off-shelf areas. Only offshelf net catches (i.e. outside the $500 \mathrm{~m}$ isobath) contained significant numbers of larvae.

\section{DISCUSSION}

The periods of egg production and early development are the most critical phases in the lifecycle of Antarctic krill. This study is the first to examine the relationship between the reproductive capacity of females and the presence of larvae in the South Georgia region. We found that females were capable of completing a full reproductive cycle around South Georgia and that most carried out 2 spawning episodes per season, releasing an average of 12343 eggs $\mathrm{yr}^{-1}$. Spawned eggs were predicted to sink to around $500 \mathrm{~m}$ and the larvae resurfaced $12 \mathrm{~d}$ after spawning, close to the first feeding stage (calyptopes I). At this point, the larvae would still retain the majority of their lipid reserves. Larvae were present in some net catches around South Georgia and were most common outside the $500 \mathrm{~m}$ isobath, which is in accord with our model predictions.

\section{Length and timing of reproductive season}

We assumed that female krill entered previtellogenesis in mid-September, around the time of the first spring blooms at South Georgia (Atkinson et al. 2001). Consequently, the first spawning events were predicted to take place from late November 


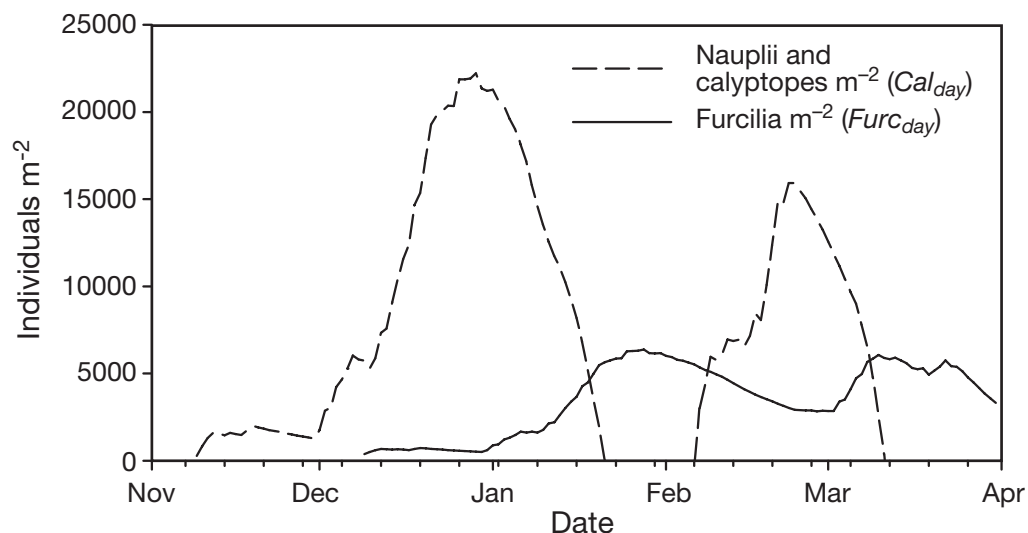

Fig. 11. Euphausia superba. Predicted concentration of nauplii and calyptopes, $\left(C a l_{d a y}\right)$ and furcilia $\left(F{ } C_{d a y}\right)$ residing in water column on each day of the productive season onwards, the majority being completed by the end of December. Our observations of ovarian stages at various times of the season around South Georgia supported these predictions (Table 3). Spawning was under way in samples taken in December (1996) and many krill were either spawning or bore evidence of previous spawns in January (2002). The fecundity model was parameterised with the ovarian stage distribution in mid-February (2003) at which point there was a mix of individuals either still spawning or preparing for the winter rest period. The period of reproduction and spawning activity at South Georgia is therefore relatively long and continuous.
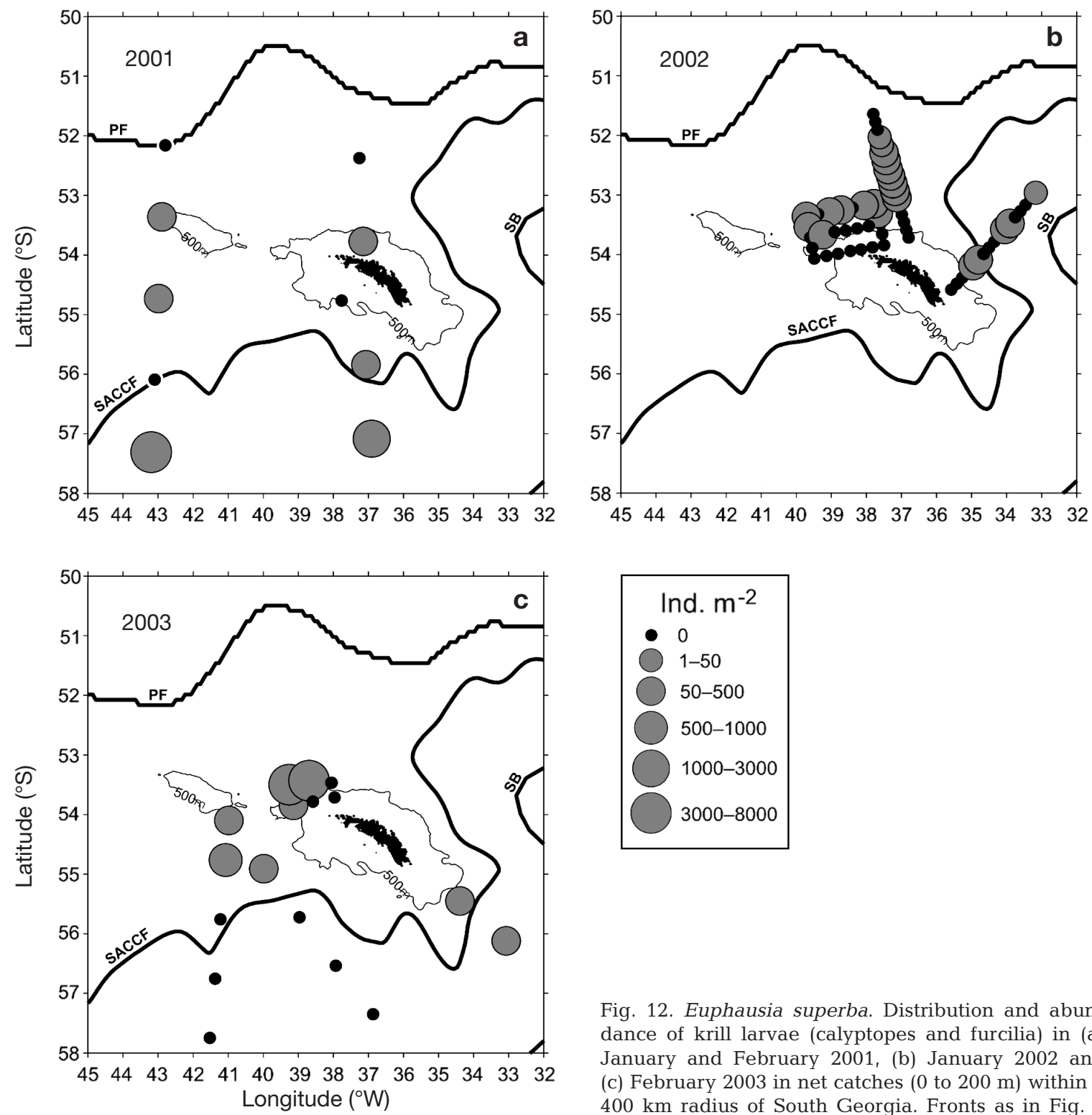

Fig. 12. Euphausia superba. Distribution and abundance of krill larvae (calyptopes and furcilia) in (a) January and February 2001, (b) January 2002 and (c) February 2003 in net catches (0 to $200 \mathrm{~m}$ ) within a $400 \mathrm{~km}$ radius of South Georgia. Fronts as in Fig. 1 
Table 8. Euphausia superba. Net catches of larvae (all calyptopes and furcilia stages) between 0 and $200 \mathrm{~m}$ within $400 \mathrm{~km}$ radius of South Georgia

\begin{tabular}{|c|c|c|c|c|c|}
\hline \multirow{2}{*}{ Cruise } & \multirow{2}{*}{$\begin{array}{l}\text { No. of } \\
\text { catches }\end{array}$} & \multicolumn{4}{|c|}{ - Larvae $\mathrm{m}^{-2}$} \\
\hline & & $\max$ & $\min$. & avg. & median \\
\hline Jan/Feb 2001 & 10 & 50814 & 0 & 5459 & 137 \\
\hline Jan 2002 & 59 & 219 & 0 & 37 & 0 \\
\hline Feb 2003 & 17 & 7008 & 0 & 754 & 0 \\
\hline
\end{tabular}

Fraser (1936) found eggs in the water column as early as the start of November in a survey of South Georgia in 1929. Nevertheless, eggs were not observed until late December in the years before and after, whilst in the 1927 to 1928 season, there were no eggs present until late February. Such variability was recognised by Spiridonov (1995) who proposed that population spawning patterns were driven by iceregime, primary productivity and physical circulation patterns. According to his study, short intense spawning seasons are normally associated with ice regions (as observed by Quetin \& Ross 2001), whereas continuous spawning over extended periods is prominent in ice-free lower latitudes. Our own observations of extended spawning at South Georgia are in line with this pattern, given that it is a relatively ice-free region at the northern limits of this species.

\section{Number of eggs per batch}

We based our estimates of the number of eggs in a batch on counts of the mature oocytes in the ovaries of ready-to-spawn ( $S D S 7$ ) females. Studies that have used this method (Jazdzewksi et al. 1978, Siegel 1985) have generally obtained higher estimates of the numbers of eggs per batch than those that have counted the number of eggs spawned (Ross \& Quetin 1983). The difference is probably a result of the fact that eggs in a batch are released over 2 or 3 partial spawns occurring over several days in the early premoult phase (Cuzin-Roudy 2000). Studies that count the numbers of eggs released normally take into account only 1 of these partial spawns.

We found that the number of eggs in a batch varied between 4300 for $45 \mathrm{~mm}$ krill and over 16000 for a $58 \mathrm{~mm}$ krill. The relationship between body size and number of eggs per batch is well established and has been reviewed by Siegel (1985). The body lengthspecific egg capacity of South Georgian krill is towards the upper range of the relationships observed elsewhere (Fig. 13). It is unlikely that these eggs were smaller than elsewhere, given that the average ovarian size of South Georgian krill ( $43 \%$ of $W W T$ ) was bigger than in many other regions (e.g. $34 \% W W T$, Nicol et al. 1995; $33 \%$ WWT Cuzin-Roudy 2000).

\section{Number of spawning episodes per season}

We predicted that most krill around South Georgia complete 2 spawning episodes per year, which is supported by the ovarian analyses. Krill sampled in December (1996) and January (2002) both showed evidence of multiple batches being prepared, with many individuals containing mature (oc4) and immature (oc2) oocytes as well as a stock of young oocytes. The development of more than 1 batch of eggs per year has yet to be observed in laboratory-reared individuals (Nicol et al. 1995). Many past attempts to estimate fecundity assumed that just 1 batch of eggs was developed per year (Bargmann 1937, Naumov 1962, Jazdzewski et al. 1978).

There is field evidence demonstrating that Antarctic krill produce multiple batches. Denys \& McWhinnie (1982) observed up to 10000 oocytes at various stages of development in mature krill ovaries. Cuzin-Roudy (2000) found more than 1 batch of eggs in krill reproducing in January. Huntley \& Brinton (1991) found 2 cohorts of larvae in the Drake Passage and Bransfield Strait, suggesting that there were several spawning episodes in this region. In their long-term study of krill reproductive characteristics in the Palmer region (1993 to 1999), Quetin \& Ross $(2001,2003)$ found evidence of successive cycles of egg production ('recycling') in 1995 and 1996, during an advanced and prolonged

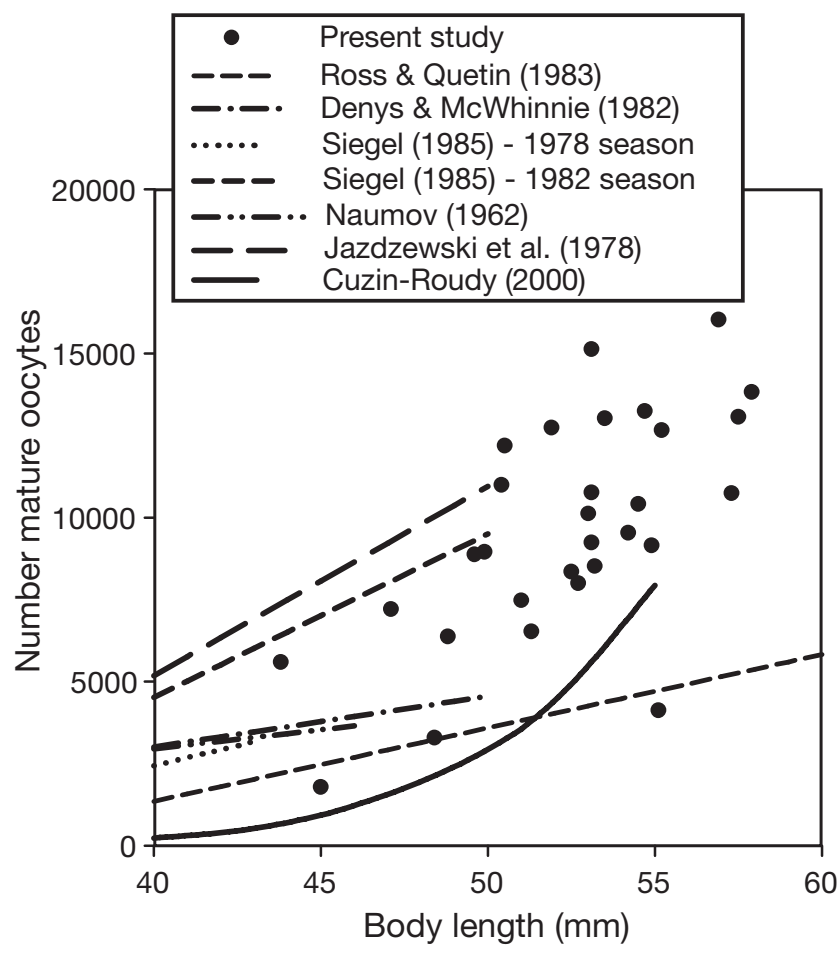

Fig. 13. Euphausia superba. Egg batch:body length relationships found by previous studies (lines) and the present study (data points) 
reproductive season. Annual primary production in these years was estimated to be 2 to 7 times higher than average.

\section{Fecundity and food limitation}

When multiplying the number of eggs per batch by the number of spawning episodes in a season, we estimated that South Georgian krill release an average of 12343 eggs $\mathrm{yr}^{-1}$ (Table 5). This is more than Clarke (1980), who estimated a mean fecundity of 7200 egg $\mathrm{yr}^{-1}$ for a $2 \mathrm{~g}$ South Georgian krill, based on the amount of lipid lost during spawning. Cuzin-Roudy (2000) made an estimate of 7500 eggs $\mathrm{yr}^{-1}$ for krill from the Scotia-Weddell seas and Prydz Bay region.

The average concentration of food in the environment and its stability throughout the summer will have a large influence on whether krill can meet their large energetic demands. Nicol et al. (1995) compared energetic requirements of krill reproduction to the energy available in the environment. They concluded that reproduction would only be possible where phyto-

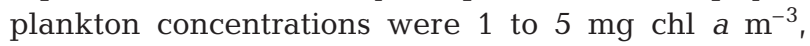
which is above the Southern Ocean average of $0.5 \mathrm{mg}$ chl a m${ }^{-3}$ (El-Sayed 1988). In January 2002, phytoplankton biomass in the north-west region of South

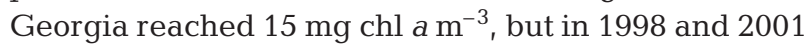
fell below $1 \mathrm{mg}$ chl a m${ }^{-3}$ (Korb \& Whitehouse 2004). Phytoplankton biomass levels also vary regionally, with values to the north-east of South Georgia rarely

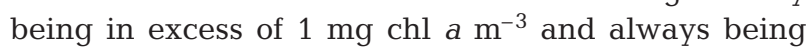
lower than those observed to the north-west (Korb \& Whitehouse 2004). The majority of South Georgian krill are found in the north-west region (Trathan et al. 2003) where phytoplankton is most abundant.

Feeding conditions were assumed to be non-limiting in the initial run of the fecundity model. However, some of the potential effects of food limitation were investigated in the sensitivity analyses of this model (Table 5). For instance, the effect of late phytoplankton blooms was simulated through delaying previtellogenesis by 20 and $40 \mathrm{~d}$. This reduced egg production to 9413 eggs $\mathrm{yr}^{-1}$ and 6878 eggs $\mathrm{yr}^{-1}$ respectively. A delay in ovarian development between 2 successive cycles of egg production, a likely product of food limitation, was simulated through requiring individuals to pass through 3 IMPs (rather than 2) for every cycle of egg production. This almost halved annual egg production to 7327 eggs $\mathrm{yr}^{-1}$. In a good year, primary productivity around South Georgia is well above that considered to be limiting to reproductive activity (Nicol et al. 1995). However, the episodic falls in primary productivity that have been observed in this region (Korb \& Whitehouse 2004) are likely to reduce egg production.

\section{Spatial limitations to larval development}

The South Georgian shelf area was not a viable region for the successful development of krill eggs when the descent-ascent parameterisation of Hofmann \& Hüsrevolğlu (2003) was applied. Successful development was predicted offshelf, where the eggs sank to between 490 and $520 \mathrm{~m}$, reaching the surface again $12 \mathrm{~d}$ after being spawned. Observations of krill larvae in offshelf regions close to South Georgia in several different years validated these predictions. This bathymetric limitation to successful development may drive distribution patterns of adult krill. Off the Antarctic Peninsula, for instance, there is a characteristic spatial separation between the juveniles, which inhabit coastal waters, and the adults, which occur over the continental slope and in oceanic regions (Siegel 1992 and references therein). Spatial segregation of adults and immature stages has also been observed in the Scotia and northern Weddell Seas (Makarov 1979) and the Bransfield Strait (Quetin \& Ross 1984). Around South Georgia, Trathan et al. (2003) found that the highest concentrations of adult krill were at the shelf edge, although swarms were also common in on-shelf regions.

Hofmann et al. (1992) found a correlation between the presence of warm CDW and krill swarms containing reproducing individuals. Throughout the Southern Ocean, CDW is found beneath AASW. The warm core of upper CDW is deep at its northernmost boundary and shoals to approximately $200 \mathrm{~m}$ at the southern boundary of the Antarctic Circumpolar Current (Orsi et al. 1995). The temperature maximum of this core changes across the Southern Antarctic Circumpolar Current Front (SACCF, Orsi et al. 1995), with colder temperatures to the south of this front. The SACCF wraps around the shelf of South Georgia (Fig. 9) influencing the oceanic environment of the island. The position of the SACCF appears fairly constant to the south and east of South Georgia. However, to the north of the island, the frontal position is variable and may move in a westward direction to encompass a large area to the north of South Georgia (Thorpe et al. 2002, Meredith et al. 2005). The northern area contains some of the highest concentrations of Antarctic krill around South Georgia (Trathan et al. 2003). The incursion of the front will bring colder CDW closer to South Georgia, which will increase the depth of hatching and may make large areas unsuitable for successful larval development. The exact biological impact of this variable frontal region requires further examination.

\section{Predicted and observed larval abundance}

Our model predicted distinct peaks and troughs in larval abundance. Predicted values reached maximum 
levels at the beginning of January (22 000 larvae $\mathrm{m}^{-2}$ ) and the end of February (19000 larvae $\mathrm{m}^{-2}$ ). Low concentrations were expected in November $(<2000$ larvae $\mathrm{m}^{-2}$ ) and at the end of January ( 6000 larvae $\left.\mathrm{m}^{-2}\right)$. Only furcilia were predicted to occur beyond mid-March.

Although 1 of the observed estimates of larval concentrations around South Georgia was above these predictions (50814 larvae $\mathrm{m}^{-2}$ in 2001, Table 8), the majority of observations were well below this level. 2001 was a good year for larval success, with average catches being around 5500 larvae $\mathrm{m}^{-2}$. The following year was relatively bad, with the maximum observed abundance being 219 larvae $\mathrm{m}^{-2}$ and the majority of stations containing no larvae at all. Observed concentrations are higher around the Antarctic Peninsula, where Brinton \& Townsend (1984) found 45000 larvae $\mathrm{m}^{-2}$ and Huntley \& Brinton (1991) 12000 larvae $\mathrm{m}^{-2}$. In the eastern Bellinghausen Sea, Pakhomov et al. (2004) found mean concentrations of almost 9000 larvae $\mathrm{m}^{-2}$ and maximum concentrations in excess of 30000 larvae $\mathrm{m}^{-2}$.

There may be a number of causes for the discrepancy between predicted and observed larval abundances around South Georgia. We were able to exclude a number of these during the course of the present study. Spawning takes place successfully in the region and egg batches contain a higher than average number of eggs. The descent-ascent cycle should be completed successfully in off-shelf regions. Food concentrations are relatively high, at least in the summer months (Korb \& Whitehouse 2004) making it unlikely that the larvae will run out of resources during the first feeding stages. Although currents are relatively strong, the larvae will not be moved out of the survey region over the first $60 \mathrm{~d}$ (Fig. 10). It is possible that the surveys were carried out in periods where there was a trough in the numbers of larvae, as was predicted for the end of January, although even then concentrations were around 6000 larvae $\mathrm{m}^{-2}$. The causes for the discrepancy must therefore lie outside those considered in this study. The following sections consider some of the most likely potential causes, namely, predation, physiological stress and advection.

\section{Predation}

The prediction of larval concentrations over the course of the year in the present study used a rate of mortality that was generic, in that it was based on global trends in zooplankton mortality and extrapolated to the situation of Euphausia superba at South Georgia (Hirst \& Kiørboe 2002). All potential sources of mortality are implicit in this rate, such as predation, parasitism, starvation and physiological stress. The rate does not account for temporal or spatial variability in mortality that may result from regional, species-specific factors. Predation mortality, in particular, has the capacity to vary spatially and temporally to a large degree depending on the distribution and abundance of predator and prey species. To date, there have been no attempts to determine the contribution of predation to the mortality rate of E. superba larvae.

Predation rates are rarely parameterised because of the difficulty in establishing feeding rates and the selectivity of predators when faced with a variety of food types. Although seasonally abundant, Euphausia superba larvae are particularly patchy in their distribution (Brinton 1985) and it is unlikely that any predator will specialise its feeding on these organisms. Nevertheless, the relatively poor motility and large energy reserves of krill larvae make them ideal prey items, and it is possible that a predator will feed on little else if a patch is located. Three of the principle predators of E. superba larvae are chaetognaths (Øresland 1990), myctophids (Pakhomov et al. 1996) and the hyperiid amphipod Themisto gaudichaudii (Pakhomov \& Perissinotto 1996).

Although specific feeding rates of these predators on Euphausia superba larvae have not been established, feeding rates in terms of prey items $\mathrm{d}^{-1}$ (Øresland 1990) or daily ration as a proportion of body weight (Pakhomov \& Perissinotto 1996, Pakhomov et al. 1996) have been determined on mixed diets (of which $E$. superba larvae was a component). Table 9 estimates the maximum number of E. superba larvae consumed $\mathrm{d}^{-1}$ assuming that the predator feeds at these rates on E. superba larvae alone. Myctophids were found to be capable of consuming more than 30 larvae $\mathrm{d}^{-1}$, while an individual Themisto gaudichaudii consumed only a tenth of that amount. Being the smallest of the 3 predators, chaetognaths have a low feeding rate in absolute terms $\left(0.5\right.$ prey d $\left.^{-1}\right)$ but this is compensated for by their high abundance around South Georgia, resulting in them being capable of consuming 200 larvae $\mathrm{m}^{-2} \mathrm{~d}^{-1}$. T. gaudichaudii are capable of consuming similar concentrations, while myctophids achieve around a quarter of that amount because of their comparatively lower abundance.

When combined, these 3 predators alone have the potential to consume almost 500 larvae $\mathrm{m}^{-2} \mathrm{~d}^{-1}$ in the South Georgia region. Exposing an initial population of 30000 larvae $\mathrm{m}^{-2}$ to this level of predation would reduce numbers to negligible amounts within $60 \mathrm{~d}$. Focussing a diet on Euphausia superba larvae alone over such a length of time is unrealistic for a pelagic predator. However, a succession of such predators feeding on a patch of larvae may rapidly diminish their numbers. 
Table 9. Maximum predation rate on Euphausia superba larvae by 3 of its major predators in the vicinity of South Georgia, assuming that alternative prey items are not consumed

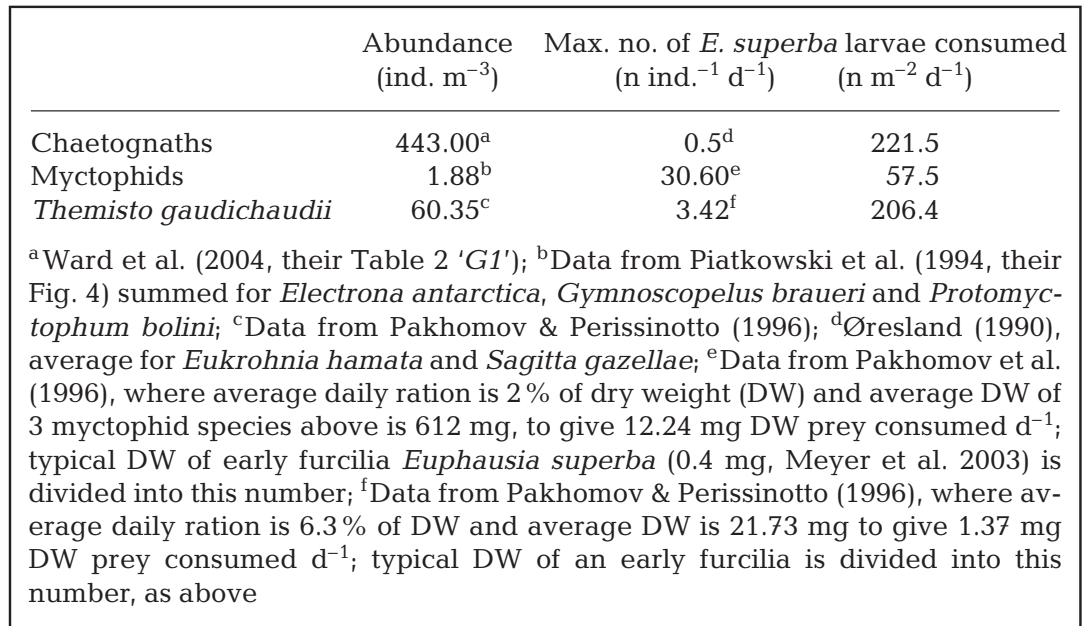

It follows that regions where larval abundance is high, such as around the Antarctic Peninsula, may be regions where there is comparatively less exposure to predation. This appears to be true with respect to chaetognaths and Themisto gaudichaudii. Chaetognaths at the Antarctic Peninsula reach just $25 \%$ of the concentrations found at South Georgia (Ward et al. 2004), while T. gaudichaudii reaches less than $10 \%$ (Kane 1966). The concentration of myctophids is approximately the same between the 2 regions (Piatkowski et al. 1994). When combined, maximum consumption rates by the 3 predators are around 130 larvae $\mathrm{m}^{-2} \mathrm{~d}^{-1}$ at the Peninsula, around $1 / 4$ of the maximum rate around South Georgia. It is not believed that there are alternative major predators of krill larvae at the Peninsula.

\section{Physiological stress}

Areas in which large concentrations of Euphausia superba larvae have commonly been found, such as the Antarctic Peninsula, have typical surface temperatures of between 0 and $2^{\circ} \mathrm{C}$ (Meredith et al. 2004). Ross et al. (1988) and Quetin \& Ross (1989) examined the effect of temperatures ranging between $-1^{\circ} \mathrm{C}$ and $2^{\circ} \mathrm{C}$ on aspects such as development time, metabolic rate and survival. Only the coldest temperatures in this range had a detrimental effect. The physiological consequences of inhabiting waters above $2^{\circ} \mathrm{C}$ has yet to be examined in E. superba larvae. A suggestion that the relatively warm surface waters around South Georgia (3 to $4{ }^{\circ} \mathrm{C}$, Meredith et al. 2005) may be detrimental to their physiological state comes from studies on adult E. superba by Atkinson et al. (2006) and
Tarling et al. (2006). Both studies examined somatic growth in relation to different environmental variables, including surface temperature. Moult rate and growth increments peaked around $2{ }^{\circ} \mathrm{C}$, and decreased either side of this temperature. The decrease at higher temperatures (up to $4^{\circ} \mathrm{C}$ ) occurred despite the fact that in situ food concentrations were commonly very high. It appeared that temperatures between 3 to $4^{\circ} \mathrm{C}$ made the environment suboptimal for E. superba, because they approached the limits of physiological tolerance. Experiments examining the response of $E$. superba larvae to such conditions are urgently required.

\section{Advection}

Despite the potential of predation to reduce larval concentrations rapidly, there remain instances where high concentrations of larvae have persisted in the South Georgia region, such as the observation of 50814 larvae $\mathrm{m}^{-2}$ in 2001 (Table 8). This suggests that there must be further forces that prevent the successful recruitment of local larvae into the adult population. The capacity of larval krill to resist prevailing advective forces is relatively weak. Over the timescale of weeks to months, we have shown that such forces are unlikely to move early-stage larvae very far from where they were spawned. However, over longer time scales, it is more likely that the larvae are transported much greater distances. Drogued drifter studies have shown that currents generally move northwards and eastwards from South Georgia (Meredith et al. 2003). This means that one possible long-term fate is towards the Polar Front, where higher temperatures make survival unlikely. An eastward displacement may have a better outcome because the larvae will be moving towards the seasonal ice zone, which could provide food and refuge during the winter months. Although many South Georgian larvae do not make it beyond the early developmental stages, it is possible that survivors have an impact on downstream populations in certain years. It remains a challenge to determine the range of these possible fates and assess how likely it is that these larvae survive the journey.

Acknowledgements. We thank the officers and crew of the RRS 'James Clark Ross' and our colleagues within the DYNAMOE and DISCOVERY 2010 programmes for their 
assistance in collection of data. G.T. also thanks E. Hofmann and S. Hüsrevolğlu for some helpful pointers when recoding their descent-ascent model and F. Buchholz for discussions on krill moulting patterns. We are grateful to the OCCAM team at the National Oceanographic Centre, Southampton, for making the OCCAM output available.

\section{LITERATURE CITED}

Atkinson A, Whitehouse MJ, Priddle J, Cripps GC, Ward P, Brandon MA (2001) South Georgia, Antarctica: a productive, cold water, pelagic ecosystem. Mar Ecol Prog Ser 216:279-308

Atkinson A, Shreeve RS, Hirst AG, Rothery P and 5 others (2006) Natural growth rates in Antarctic krill (Euphausia superba): II. Predictive models based on food, temperature, body length, sex, and maturity stage. Limnol Oceanogr 51:973-987

Bargmann HE (1937) The reproductive system of Euphausia superba. Discov Rep 14:327-349

Brinton E (1962) The distribution of Pacific euphausiids. Bull Scripps Inst Oceanogr Univ Calif 8:51-270

Brinton E (1976) Population biology of Euphausia pacifica off Southern California. US Fish Wildl Serv Fish Bull 74: 733-763

Brinton E (1985) The oceanographic structure of the eastern Scotia Sea. III. Distributions of euphausiid species and their developmental stages in 1981 in relation to hydrography. Deep-Sea Res 32:1153-1180

Brinton E, Townsend AW (1984) Regional relationships between development and growth in larvae of Antarctic krill, Euphausia superba, from field samples. J Crustac Biol 4:224-246

Clarke A (1980) The biochemical composition of krill Euphausia superba (Dana), from South Georgia. J Exp Mar Biol Ecol 43:221-236

Cuzin-Roudy J (1987) Gonad history of Antarctic krill Euphausia superba Dana during its breeding season. Polar Biol 7:237-244

Cuzin-Roudy J (1993) Reproductive strategies of the Mediterranean krill, Meganyctiphanes norvegica and the Antarctic krill Euphausia superba (Crustacea: Euphausiacea). Invertbr Reprod Dev 23:105-114

Cuzin-Roudy J (2000) Seasonal reproduction, multiple spawning, and fecundity in northern krill, Meganyctiphanes norvegica, and Antarctic krill, Euphausia superba. Can J Fish Aquat Sci 57:6-15

Cuzin-Roudy J, Amsler MO (1991) Ovarian development and sexual maturity staging in Antarctic krill, Euphausia superba Dana (Euphausiacea). J Crustac Biol 11:236-249

Cuzin-Roudy J, Buchholz F (1999) Ovarian development and spawning in relation to the moult cycle in Northern krill Meganyctiphanes norvegica (Crustacea: Euphausiacea), along a climatic gradient. Mar Biol 133:267-281

Cuzin-Roudy J, Labat JP (1992) Early summer distribution of Antarctic krill sexual development in the Scotia-Weddell region: a multivariate approach. Polar Biol 12:65-74

Dalpadado P, Skjoldal HR (1991) Distribution and life history of krill from the Barents Sea. Polar Res 10:443-460

Denys CJ, McWhinnie MA (1982) Fecundity and ovarian cycles of the Antarctic krill Euphausia superba (Crustacea, Euphausiacea). Can J Zool 60:2414-2423

de Visser J (1986) Transition zones and salp speciation. In: Pierrot-Bults AC, van der Spoel S, Zahuranec BJ, Johnson RK (eds) Pelagic biogeography. UNESCO, Paris, p 266-269
El-Sayed SZ (1988) Seasonal and interannual variabilities in Antarctic phytoplankton with reference to krill distribution. In: Sahrhage D (ed) Antarctic ocean resources and variability. Springer-Verlag, Berlin, p 101-119

Fraser FC (1936) On the development of the young stages of krill (Euphausia superba). Discov Rep 14:1-192

Hirst AG, Kiørboe T (2002) Mortality of marine planktonic copepods: global rates and patterns. Mar Ecol Prog Ser 230:195-209

Hofmann EE, Hüsrevolğlu YS (2003) A circumpolar modeling study of habitat control of Antarctic krill (Euphausia superba) reproductive success. Deep-Sea Res II 50: 3121-3142

Hofmann EE, Capella JE, Ross RM, Quetin LB (1992) Models of the early life history of Euphausia superba. 1. Time and temperature-dependence during the descent ascent cycle. Deep-Sea Res A 39:1177-1200

Huntley M, Brinton E (1991) Mesoscale variation in growth and early development of Euphausia superba Dana in the western Bransfield Strait region. Deep-Sea Res 38: $1213-1240$

Jazdzewksi K, Dzik J, Porebski J, Rakusa-Suszczewski S, Witek Z, Wolnomiejski N (1978) Biological and populational studies on krill near South Shetland Islands, Scotia Sea and South Georgia in the summer 1976. Pol Arch Hydrobiol 25:607-631

Kane JE (1966) The distribution of Parathemisto gaudichaudii (Guer) with observations on its life-history in the $0^{\circ}$ to $20^{\circ}$ sector of the Southern Ocean. Discov Rep 34:163-198

Killworth P (1996) Time interpolation of forcing fields in ocean models. J Phys Oceanogr 26:136-143

Korb RE, Whitehouse M (2004) Contrasting primary production regimes around South Georgia, Southern Ocean: large blooms versus high nutrient, low chlorophyll waters. Deep-Sea Res I 51:721-738

MacDonald PDM, Green PEJ (1988) User's guide to program MIX: an interactive program for fitting mixtures of distributions. Icthus Data Systems, Hamilton

Mackintosh NA (1972) Life-cycle of Antarctic krill in relation to ice and water conditions. Discov Rep 36:1-94

Makarov RR (1979) Early larval stages of Antarctic euphausiids (in Russian). Zool Zh 58:314-327

Makarov RR, Denys CJ (1980) Stages of sexual maturity of Euphausia superba, Biomass Handbook 11 SCAR, Cambridge

Marschall HP (1983) Sinking speed, density and size of euphausiid eggs. Meeresforschung 30:1-9

Mauchline J (1977) Growth and moulting of Crustacea, especially euphausiids. In: Andersen NR, Zahuranec BJ (eds) Oceanic sound scattering and prediction. Plenum Press, New York, p 401-422

Meredith MP, Watkins JL, Murphy EJ, Cunningham NJ, Wood AG, Korb R, Whitehouse MJ, Thorpe SE (2003) An anticyclonic circulation above the Northwest Georgia Rise, Southern Ocean. Geophys Res Lett 30:2061-2066

Meredith MP, Renfrew IA, Clarke A, King JC, Brandon MA (2004) Impact of the 1997/1998 ENSO on upper ocean characteristics of Marguerite Bay, western Antarctic Peninsula. J Geophys Res (C9) C09013, doi: 10.1029/2003 JC001784001719

Meredith MP, Brandon MA, Murphy EJ, Trathan PN, Thorpe SE, Bone DG, Chernyshkov PP, Sushin VA (2005) Variability in hydrographic conditions to the east and northwest of South Georgia, 1996-2001. J Mar Syst 53:143-167

Meyer B, Atkinson A, Blume B, Bathmann UV (2003) Feeding and energy budgets of larval Antarctic krill Euphausia superba in summer. Mar Ecol Prog Ser 257:167-177 
Moore JK, Abbott MR, Richman JG (1999) Location and dynamics of the Antarctic Polar Front from satellite sea surface temperature data. J Geophys Res C 104:3059-3073

Morris DJ, Watkins JL, Ricketts C, Buchholz F, Priddle J (1988) An assessment of the merits of length and weight measurements of Antarctic krill Euphausia superba. Br Antarct Surv Bull 79:27-50

Murphy EJ, Reid K (2001) Modelling Southern Ocean krill population dynamics: biological processes generating fluctuations in the South Georgia ecosystem. Mar Ecol Prog Ser 217:175-189

Murphy EJ, Watkins JL, Reid K, Trathan PN and 6 others (1998) Interannual variability of the South Georgia marine ecosystem: biological and physical sources of variation in the abundance of krill. Fish Oceanogr 7:381-390

Murphy EJ, Thorpe SE, Watkins JL, Hewitt R (2004) Modelling the krill transport pathways in the Scotia Sea: spatial and environmental connections generating the seasonal distribution of krill. Deep-Sea Res II 51:1435-1456

Naumov AG (1962) Biological state of aggregations of Euphausia superba Dana found near the Balleny Islands. Inf Byull Sov Antarkt Eksped 4:277-280

Nicol S, de la Mare WK, Stolp M (1995) The energetic cost of egg production in Antarctic krill (Euphausia superba Dana). Antarct Sci 7:25-30

Øresland V (1990) Feeding and predation impact of the chaetognath Eukrohnia hamata in Gerlache Strait, Antarctic Peninsula. Mar Ecol Prog Ser 63:201-209

Orsi AH, Whitworth T, Nowlin WD (1995) On the meridional extent and fronts of the Antarctic Circumpolar Current. Deep-Sea Res I 42:641-673

Pakhomov EA, Perissinotto R (1996) Trophodynamics of the hyperiid amphipod Themisto gaudichaudii in the South Georgia region during late austral summer. Mar Ecol Prog Ser 134:91-100

Pakhomov EA, Perissinotto R, McQuaid CD (1996) Prey composition and daily rations of myctophid fishes in the Southern Ocean. Mar Ecol Prog Ser 134:1-14

Pakhomov EA, Atkinson A, Meyer B, Oettl B, Bathmann U (2004) Daily rations and growth of larval krill Euphausia superba in the Eastern Bellingshausen Sea during austral autumn. Deep-Sea Res II 51:2185-2198

Peck LS, Webb KE, Bailey DM (2004) Extreme sensitivity of biological function to temperature in Antarctic marine species. Funct Ecol 18:625-630

Piatkowski U, Rodhouse PG, White MG, Bone DG, Symon C (1994) Nekton community of the Scotia Sea as sampled by the RMT25 during austral summer. Mar Ecol Prog Ser 112:13-28

Quetin LB, Ross RM (1984) Depth distribution of developing Euphausia superba embryos, predicted from sinking rates. Mar Biol 79:47-53

Quetin LB, Ross RM (1989) Effects of oxygen, temperature and age on the metabolic rate of the embryos and early

Editorial responsibility: Otto Kinne (Editor-in-Chief), Oldendorf/Luhe, Germany larval stages of the Antarctic krill Euphausia superba Dana. J Exp Mar Biol Ecol 125:43-62

Quetin LB, Ross RM (2001) Environmental variability and its impact on the reproductive cycle of Antarctic krill. Am Zool 41:74-89

Quetin LB, Ross RM (2003) Episodic recruitment in Antarctic krill Euphausia superba in the Palmer LTER study region. Mar Ecol Prog Ser 259:185-200

Quetin LB, Ross RM, Frazer TK, Amsler MO, Wyattevens C, Oakes SA (2003) Growth of larval krill, Euphausia superba, in fall and winter west of the Antarctic Peninsula. Mar Biol 143:833-843

Ross RM, Quetin LB (1983) Spawning frequency and fecundity of the Antarctic krill Euphausia superba. Mar Biol 77:201-205

Ross RM, Quetin LB (2000) Reproduction in Euphausiacea. In: Everson I (ed) Krill: biology, ecology and fisheries, Vol 6. Blackwell Science, Oxford, p 150-181

Ross RM, Quetin LB, Kirsch E (1988) Effect of temperature on developmental times and survival of early larval stages of Euphausia superba Dana. J Exp mar Biol Ecol 121:55-71

Ruud JT (1932) On the biology of southern Euphausiidae. Hvalråd Skr 2:1-105

Siegel V (1985) On the fecundity of Antarctic krill, Euphausia superba (Euphausiacea). Archiv FischWiss 36:185-193

Siegel V (1992) Assessment of the krill (Euphausia superba) spawning stock off the Antarctic peninsula. Arch Fischwiss 41:101-130

Spiridonov VA (1995) Spatial and temporal variability in reproductive timing of Antarctic krill (Euphausia superba Dana). Polar Biol 15:161-174

Tarling GA, Shreeve RS, Hirst AG, Atkinson A, Pond DW, Murphy EJ, Watkins JL (2006) Natural growth rates in Antarctic krill (Euphausia superba). I. Improving methodology and predicting intermolt period. Limnol Oceanogr 51:959-972

Thorpe SE, Heywood KJ, Brandon MA, Stevens DP (2002) Variability of the southern Antarctic Circumpolar Current front north of South Georgia. J Mar Syst 37:87-105

Trathan PN, Brierley AS, Brandon MA, Bone DG, Goss C, Grant SA, Murphy EJ, Watkins JL (2003) Oceanographic variability and changes in Antarctic krill (Euphausia superba) abundance at South Georgia. Fish Oceanogr 12: 569-583

Ward P, Atkinson A, Peck JM, Wood AG (1990) Euphausiid life cycles and distribution around South Georgia. Antarct Sci 2:43-52

Ward P, Grant S, Brandon M, Siegel V, Sushin V, Loeb V, Griffiths H (2004) Mesozooplankton community structure in the Scotia Sea during the CCAMLR 2000 survey: JanuaryFebruary 2000. Deep-Sea Res II 51:1351-1367

Webb DJ, de Cuevas BA (2003) The region of large sea surface height variability in the Southeast Pacific Ocean. J Phys Oceanogr 33:1044-1056

Submitted: November 24, 2005; Accepted: May 24, 2006

Proofs received from author(s): January 25, 2007 